\title{
Theory of glacial erosion, transport and deposition as a consequence of subglacial sediment deformation
}

\author{
G. S. Boulton \\ Department of Geology and Geophysics, Grant Institute, University of Edinburgh, Edinburgh EH9 3yH, Scotland
}

\begin{abstract}
A theory of erosion, transport and deposition of unlithified sediments by glaciers is presented. It predicts the large-scale areal distribution of zones and rates of erosion and deposition in time and space through a complete glacial cycle, together with the resultant intensity of large-scale lineations drumlins) which will be incised in the landscape. The theory also predicts the dispersal patterns of subglacial lithologies, together with the form of dispersal trains derived from distinctive sources and the vertical and horizontal distribution of lithologies within a till. It predicts major erosional discontinuities within tills and the formation of boulder pavements. It suggests that the dominant proportion of the lowland tills produced by Pleistocene mid-latitude ice sheets was generated by subglacial deformation and explains why they are predominantly fine-grained.

The theory is based on an analysis of glacier-dynamic processes and therefore can be used to infer the dynamic behaviour of former ice sheets from the distribution of tills and their lithologic composition.
\end{abstract}

\section{INTRODUCTION}

Prior to the last decade, it had generally been assumed that glaciers moved over rigid substrata and that the rheology of ice and the processes of sliding of ice over this rigid bed determined the dynamic response of the glacier to changes in surface mass balance (Fig. $1 \mathrm{a}$ and $\mathrm{b}$ ).

Similarly, it had been implicitly assumed that the processes of erosion and deposition which occur when glaciers flow over rock beds were universally applicable. In these processes, subglacially crushed detritus is incorporated in the ice by freezing, transported englacially and released basally from the glacier by lodgement or supraglacially by melting-out. No-one had explicitly addressed the question of erosion and deposition on beds of unlithified sediment.

However, many modern glaciers rest, at least in part, on unlithilied beds, and large areas of the Pleistocene ice sheets in the mid-latitudes of Europe and North America were underlain by thick, unlithified sediment sequences. Understanding erosion and deposition on such a bed is thus important; not only for geological reasons but because the (a)

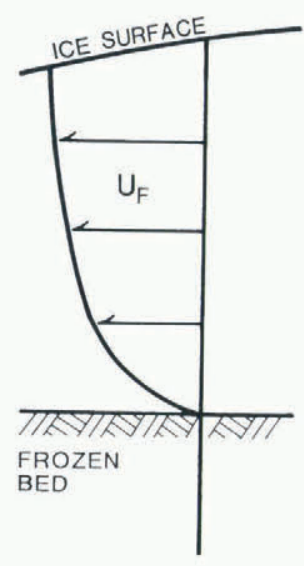

(b)

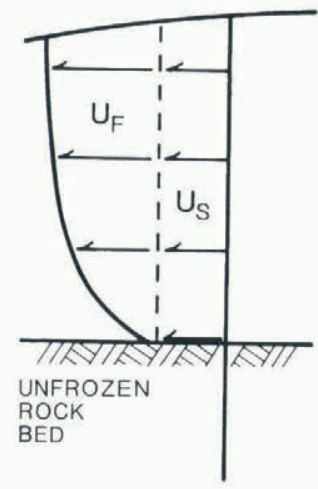

(c)

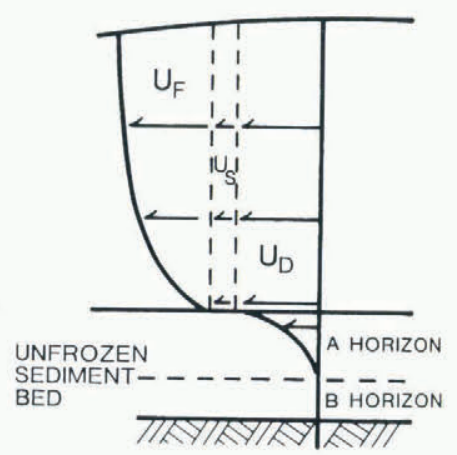

Fig. 1. Schematic diagrams showing the horizontal velocity distribution in sections through a glacier resting on: (a) a frozen bed (rock or unlithified sediment); (b) a rigid bed but with sliding along an unfrozen glacier/bed contact; (c) a deforming bed. There are three possible velocity components: internal flow $\left(U_{\mathrm{f}}\right)$; basal sliding $\left(U_{\mathrm{S}}\right)$; deformation of subglacial sediments $\left(U_{\mathrm{D}}\right)$. If the longiludinal ice flux is approximalely conslant in all cases, it will be discharged through a progressively thinner. lower-sloped glacier in going from case (a) to case (c). 
strong coupling which it is suggested can occur between the glacier and such a bed can have a major influence on a glacier's dynamics and its role in climate change.

Boulton and Jones (1979) suggested that the rheology of deforming subglacial sediments could be a major determinant of the dynamic behaviour of ice sheets (Fig. 1c). Alley and others (1987) demonstrated the reality of this process beneath the West Antarctic ice sheet and that the dynamics of at least one of its major ice streams was largely controlled by the deformation of water-soaked sediment. Engelhardt and others 1990 confirmed, by drilling, the presence of such sediment. Boulton (1987) explored the consequences of subglacial deformation for processes of erosion and deposition, and suggested that, in the sediment-covered lowlands which underlay much of the outer zones of midlatitude ice sheets, sediment deformation played the dominant role in glacial erosion and deposition and in the production of tills and drumlins, and that most of the constituents of such tills had not been transported by conventional englacial mechanisms.

This paper develops a theory of large-scale erosion and deposition produced by an ice sheet resting on an unlithified sediment bed. For the sake of simplicity, it is assumed that such a bed occurs beneath the whole of the ice sheet. For the ice sheets which covered large parts of North America and northwest Europe during the last glacial period, much of the outer zones were underlain by soft sediment and the inner zones predominantly by bedrock. Although a complete description of subglacial erosion and deposition requires integration of "hard-bed", and "soft-bed" theories, it will be argued in a later paper that the approach taken below can be applied to both and therefore that the conclusions of this paper can be applied qualitatively to a "hard bed".

The effects of fluvial reworking of till are ignored in the theory. Not because they are not important but because they are superimposed upon the patterns predicted here, and it is the reality of those primary patterns which will test the theory. A fluvial reworking theory, though desirable, can be regarded as a separate issue.

\section{EROSION, TRANSPORT AND DEPOSITION ON AN UNLITHIFIED, DEFORMING BED}

Consider a glacier whose sole is at the melting point and underlain by unlithified sediments into which subglacial meltwater is discharged. Boulton and Jones (1979) showed that, beneath a large glacier, any significant thickness of fine-grained (clay- or silt-rich) sediment would be enough to impede interstitial drainage to the extent of producing zero effective pressure in the sediment, resulting in little or no frictional resistance beneath the glacier and producing "unstable" deformation which could lead to a surge. Boulton and Hindmarsh (1987) suggested, however, that unstable deformation at zero effective pressure would lead to "piping" so as to produce sediment-floored tunnels which would drain excess water and re-establish stable deformation and restabilize the sediment/glacier system. An equilibrium would be maintained in which major perturbations which tended to increase interstitial water pressures would be counteracted by the production of further tunnels or the enlargement of existing ones, whilst reduction in water pressure would be counteracted by tunnel closure. It was suggested that the subglacial system thus adjusts itself to climatically determined ice discharge and, notwithstanding the potentially complex behaviour of subglacial till (Clarke, 1987), the average frictional resistance which a given bed offers to a given glacier need not be highly variable. It is argued thus that there are internal mechanisms which buffer external perturbations and maintain stable operation of the system.

From the observations of Boulton and Jones (1979) and Boulton and Hindmarsh (1987) at the Breidamerkurjökull experimental sites, and their theoretical explanations, it is suggested that subglacial shear deformation occurs when subglacial drainage is so poor that high porewater pressures, and therefore low effective pressures, develop in the sediments immediately beneath the glacier sole above a level $z_{\mathrm{A}}$, where effective pressures are no longer large enough to prevent deformation (Figs lc and 2 ). This defines a tectonic A horizon within which shear (a)

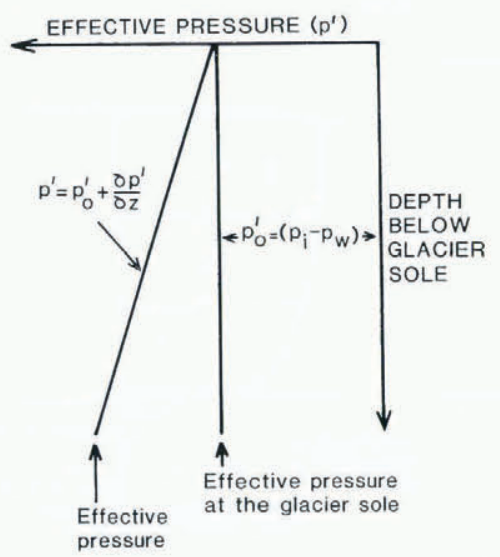

(b)

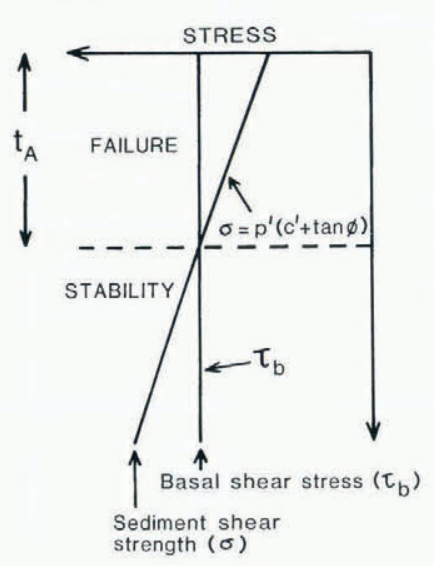

(c)

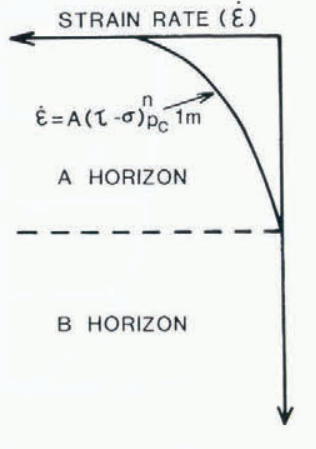

Fig. 2. The pattern of effective pressure, stress and strain in a deforming subglacial sediment. (a) shows the distribution of subglacial effective pressure which determines the sediment shear strength. Effective pressure at the glacier sole $\left(p_{0}^{\prime}\right)$ will be finite or zero. (b) shows an increasing sediment shear strength with depth which is a linear function of effective pressure, and which eventually exceeds the constant value of shear stress at depth $t_{\mathrm{A}}$, below which no further deformation will occur. (c) shows the distribution of strain rate in the deforming A horizon, overlying a stable $B$ horizon. Strain rate depends on shear stress and sediment strength. 
deformation tends to cause dilation of the grain skeleton, producing a much lower density than in the underlying, undeformed and consolidated B horizon.

A Coulomb failure criterion is used to define the shear strength $\sigma)$ of the sediment:

$$
\sigma=p^{\prime} \tan \phi+c
$$

where $c$ is the cohesion, $\phi$ is the angle of internal friction of the sediments and $p^{\prime}$ is effective pressure. Beneath the glacier sole, $p^{\prime}$ will increase with depth in the following way (Fig. 2a):

$$
\frac{\delta p^{\prime}}{\delta z}=(1-n)\left(\rho_{\mathrm{s}}-\rho_{\mathrm{w}} g-\frac{m \rho_{\mathrm{w}}}{k} g\right.
$$

(Boulton and Dobbie, 1993)

where $n$ is the void ratio of the sediment, $\rho_{\mathrm{s}}$ is the density of sediment grains, $\rho_{\mathrm{w}}$ is the density of water, $m$ is the basal melting rate, $k$ is the sediment permeability and $g$ is the acceleration due to gravity. $(1-n)\left(\rho_{\mathrm{s}}-\rho_{\mathrm{w}}\right) g$ is a term which describes the increase of buoyant weight with depth, and $\left(m \rho_{w} / k\right) g$, a term due to the potential gradient generated by the flux of meltwater $(m)$ through the sediment. If the sediment has a relatively high permeability, greater than about $10^{7}-10^{8} \mathrm{~ms} \mathrm{~s}^{-1}$ Boulton and Dobbie, 1993), the potential gradient $\delta p^{\prime} / \delta z$ within it will be a typical gravitational gradient of about $10 \mathrm{kPam}^{-1}$. Under this latter circumstance, the second term on the righthand side of Equation (2) will be zero, as it will be if there is no vertical water flux.

The effective pressure $p^{\prime}$ at any depth $(z)$ will be:

$$
p^{\prime}=p_{0}^{\prime}+\frac{\delta p^{\prime}}{\delta z} z
$$

where $p_{0}^{\prime}$ is the effective pressure at the glacier sole. The shear stress at the base of the glacier $\left(\tau_{\mathrm{b}}\right)$ is assumed to be constant with depth in the sediment, whilst $p^{\prime}$ increases with depth (Fig. 2a and b). Deformation will cease at a depth $\left(z_{\Lambda}\right)$ where shear stress equals shear strength $\left(\tau_{\mathrm{b}}=\sigma\right)$ :

$$
\tau_{\mathrm{b}}=\left(p_{0}^{\prime}+t_{\mathrm{A}} \frac{\delta p^{\prime}}{\delta z}\right)(c+\tan \phi)
$$

so that

$$
z_{\mathrm{A}}=\frac{\left(\frac{\tau_{\mathrm{b}}}{(c+\tan \phi)}-p_{0}^{\prime}\right)}{\frac{\delta p^{\prime}}{\delta z}}
$$

Boulton and Hindmarsh (1987) suggested two flow laws for a deforming sediment, one of which assumed nonlinearly viscous behaviour so that:

$$
\dot{\epsilon}=A \frac{\tau_{\mathrm{b}}{ }^{n}}{p^{\prime m}}
$$

where $\dot{\epsilon}$ is the shear strain rate and $A, n$ and $m$ are constants. The $\mathrm{A} / \mathrm{B}$ interface is assumed to form a rigid surface above which sediment in the $\mathrm{A}$ horizon deforms as a viscous fluid. The velocity $U$ ) at any point in the $A$ horizon, due to incremental strain within it, is found by integrating from the base of the deforming $A$ horizon:

$$
U(x)=\int_{z}^{z+1} \dot{\epsilon} \delta z .
$$

Substituting Equations (3) and (6) into Equation (7 gives:

$$
U(z)=\int^{z_{A}} \frac{\left(A \tau_{b}\right)^{n}}{\left(p_{0}^{\prime}+\frac{\delta p^{\prime}}{\delta} z\right)^{m}} \delta z .
$$

$\delta p^{\prime} / \delta z$ can be regarded as constant. The equation is solved numerically.

The horizontal flux of sediment within the deforming A horizon $\left.Q_{\mathrm{A}}\right)$ will be:

$$
Q_{\mathrm{A}}=\int_{0}^{z_{\mathrm{A}}} U \delta z
$$

which is also solved numerically.

If, in a steady state, the flux of sediment increases in the down-glacier direction $\delta Q_{\mathrm{A}} / \delta x$ positive), more material must be added to the deforming $\mathrm{A}$ horizon in order to maintain continuity (Fig. 3a). This can only be achieved by progressively lowering the interface between the deforming horizon and the underlying, hitherto stable horizon, which is thereby eroded by being drawn into the flow. The hitherto stable bed is eroded because of the increasing flux in the $\mathrm{A}$ horizon and the $\mathrm{A} / \mathrm{B}$ plane is lowered. Conversely, if the sediment flux diminishes down-glacier $\delta Q_{\mathrm{A}} / \delta x$ negative), mass must be lost from the deforming horizon (Fig. 3b), which will occur by hitherto mobile material accumulating at the base of the deforming horizon and resulting in a rise of the $\mathrm{A} / \mathrm{B}$ plane.

The rate of erosion $(\dot{E})$ will be:

$$
\dot{E}=\frac{\delta Q_{\mathrm{A}}}{\delta x} .
$$

(a)

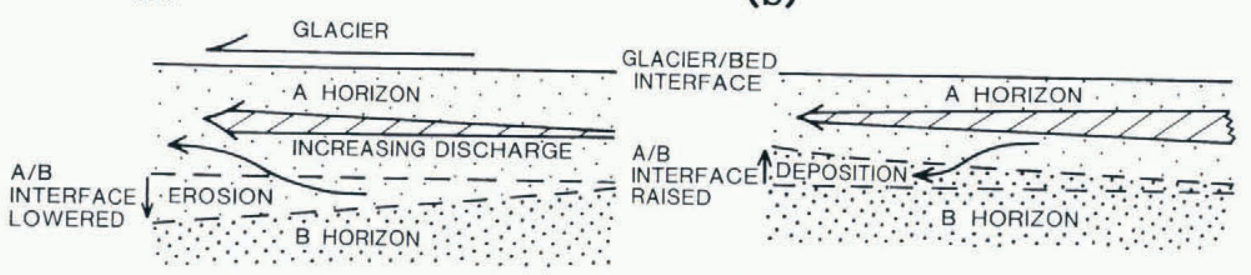

Fig. 3. The conditions for erosion and deposition on a deforming bed. In (a), longitudinally or lemporally increasing ice flux is associaled with higher shear stress and increasing sediment discharge, causing malerial from the stable $B$ horizon to be added to the mobile $A$ horizon, lowering of the $A / B$ interface and erosion. (b) shows the converse case of deposition resulting from longitudinal compression. 
Erosion will occur when $(\dot{E})$ is positive and deposition when negative. In the erosional case, sediment passes from the stable to the deforming horizon and in the depositional case from the deforming to the stable horizon. For the purpose of this paper, a thick stratum of unlithified material is assumed. If lithified bedrock is exposed during erosion, the mechanism of erosion will change and the rate of erosion will be reduced.

\section{PATTERNS OF SOFT-BED EROSION AND DEP- OSITION BENEATH A STEADY-STATE ICE SHEET}

It is clear that there is strong coupling between the dynamics of an ice sheet and sediment deformation beneath it. A steady-state ice-sheet profile must be compatible with the deforming-bed rheology and the icesheet surface mass balance. Flow in the bed will be driven by the basal shear stress, given by the ice-sheet profile, and the bed rheology will depend upon the subglacial effective pressure distribution, which is a function of the melting rate and drainage. We therefore seek a relationship between mass balance, shear stress and effective pressure. Boulton and Jones (1979) analyzed the coupling between ice-sheet mass balance and shear stress for a bed of given rheology, assuming a constant effective pressure in the bed. Unfortunately, we still do not have an adequate physical understanding of subglacial drainage processes in order to analyze the hydraulic component of effective pressure and therefore to analyze the full coupled system.

Röthlisberger (1972), Weertman 1972) and Nye (1973) analyzed the flow of water in tunnels over a rigid bed. Alley (1992) showed that tunnels on the deforming bed of a glacier could not be fed from water flowing at the glacier/bed interface. Fowler and Walder (1993) suggested that drainage in such a situation might occur through "canals" in the till, and Clark and Walder (1994) suggested that the abrupt termination of eskers at the edge of the shield areas in Europe and North America might reflect a change from tunnels to canals. Boulton and others (1993, paper in preparation) have demonstrated that ground-water flow can play a major role in ice-sheet hydraulics. However, more work is required before these processes can be integrated in such a way as to provide a drainage theory which relates effective pressure to ice-sheet dynamics and so permits a properly coupled sheet/sediment dynamics problem to be solved.

It is therefore assumed that shear stress distribution is known, and from this is calculated the effective pressure and distribution of sediment deformation which would be compatible with it for a given ice-sheet-surface massbalance distribution. A constant basal effective pressure could equally be assumed and the shear stress and sediment deformation calculated which would be compatible with this for a given mass balance. The resulting general patterns of erosion and deposition are similar.

It is assumed that there is no slip between a sediment bed of constant lithology and the ice-sheet sole (it would be a simple matter to include slip), and that the forward movement of the ice sheet is entirely accounted for by deformation. A similar approach was successfully used by Nye (1959) to compute the theoretical profile of an ice sheet. He argued that most of the flow of an ice sheet occurred at or near its bed and thus that its longitudinal profile could be modelled by assuming basal sliding but no internal flow. Using a sliding law of the form $U_{\mathrm{b}}=B \tau_{\mathrm{b}}{ }^{n-1}$, where $B$ and $n$ are flow-law parameters, he showed that the profile should be

$$
\left(\frac{h}{H}\right)^{2+\frac{1}{h}}+\left(\frac{x}{L}\right)^{1+\frac{1}{h}}=1
$$

where $H$ is the ice thickness at the divide, $L$ is the distance from the divide to the terminus, $h$ and $x$ are local ice thickness and distance from the divide, respectively, and $b$ is a flow-law parameter.

As a flow law for deforming sediments (Equation (6)) is similar to that for ice, and as effective pressure has been suggested as having a similar role in governing friction on a hard bed (Morland, 1984) as on a soft bed, we might expect a profile similar to that described by Equation (11) to apply to a deforming bed, although with different parameters. This should apply unless there is a major change in fundamental properties of the bed, such as the change from granitic rocks with little soft-sediment cover to sedimentary rocks with an ample soft-sediment cover, where Boulton and Jones (1979) suggested that a "Mexican hat" profile could develop. In such a case, as in the case of a rigid bed, we might expect the drainage system to adapt itself, much as it is presumed to do on a hard bed, to control effective pressures so that flow in the till layer discharges the appropriate ice-mass flux. A generalized mechanism for effective pressure control was suggested by Boulton and Hindmarsh (1987) and has been amplified by Boulton and others (paper in preparation). That there is a mechanism which controls effective pressure in the case of a soft bed is strongly suggested by the measurements of Fountain 1994 on the South Cascade Glacier, which does not appear to have a history of surging, where a subglacial sediment layer is assumed and where effective pressures are uniformly between 100 and $150 \mathrm{kPa}$, except in the vicinity of a subglacial channel. This would produce conditions very close to failure in most coarse-grained tills along most of the length of the glacier.

It has therefore been assumed that an ice sheet on a deformable bed with uniform hydrogeological properties will have a parabolic profile of the general form given by Equation (11).

It is assumed that movement occurs as a result of displacement at the ice/bed interface due to shear in underlying sediments (sliding is assumed not to occur at the ice/bed interface because of the roughness of an ice/ sediment interface). The ice discharge due to deformation in underlying sediments will be:

$$
Q_{\mathrm{s}}=U_{\mathrm{b}} h
$$

where $U_{\mathrm{b}}$ is the velocity at the ice/bed interface (given by Equation (8) integrated to $z=0$ ). The ice discharge is a function of mass balance $(\alpha)$, which is positive in the accumulation area and negative in the ablation area:

$$
Q_{\mathrm{i}}=\int_{x}^{x=0} \alpha \delta x
$$

where $\rho_{\mathrm{i}}$ is ice density and $x$ is the distance from the ice 
divide. Combining Equations (8), (12) and (13) gives:

$$
h\left[\int \frac{\left(A \tau_{\mathrm{b}}\right)^{n}}{\left(p_{0}^{\prime}+\frac{\delta p^{\prime}}{\delta z}\right)^{m}} \delta z\right]=\int_{x}^{x=0} \alpha \delta x .
$$

Values of $p_{0}^{\prime}$ which are compatible with values of $U_{\mathrm{b}}$, and the values of $\tau_{b}$, given by Equation (11) are derived by integration of Equation (8) to the glacier sole:

$$
U_{\mathrm{b}}=\int^{z_{1}} \frac{\left(A \tau_{\mathrm{b}}\right)^{n}}{\left(p_{0}^{\prime}+\frac{\delta p^{\prime}}{\delta z} z\right)^{m}} \delta z .
$$

Results are shown in Figure 4 for an ice sheet of $500 \mathrm{~km}$ span, a divide elevation of $2.8 \mathrm{~km}$, a mean accumulation rate of $0.5 \mathrm{~m} \mathrm{a}^{1}$ and for a sandy Icelandic till, a silty till from The Netherlands (Table 1 ) and a clay till.

The analysis implicitly assumes that a mechanism exists to adjust the effective pressure at the glacier sole, and thereby deforming layer thickness, so that the basal velocity is able to balance the ice flux. As can be seen in Figure 4d, the effective pressure must remain relatively constant along the flowline in order to maintain stable deformation.

Figure 4 also shows calculated values of deforming horizon thickness (Fig. 4a), discharge in the deforming horizon (Fig. 4b) and rates of erosion and deposition (Fig. $4 \mathrm{c})$.

The thickness of the deforming horizon increases from zero beneath the divide region to a maximum in the vicinity of the equilibrium line and decreases to zero at the terminus. Both the mean velocity and discharge show a similar pattern, although they are slightly offset in relation to each other. The rate of erosion is zero or very low in a broad region near to the divide and rises to a maximum just up-glacier of the equilibrium line, where the rate of increase of discharge in the deforming horizon is greatest. It then decreases to zero beneath the equilibrium line, beyond which we pass to a zone of deposition.

Table 1. Values of non-linearly viscous flow-law parameters for a sandy lill from Breidamerkurjökull, a silty Saalian till from The Netherlands and a clay quoled by kamb (1991). No A parameter can be inferred for the clay-rich till from Kamb's (1991) paper

\section{$A$}

$n$

$m$

\begin{tabular}{lccc}
\hline Sand-rich till & 3.99 & -1.8 & 1.33 \\
Silt-rich till & $10^{13}$ & 13.7 & 15.9 \\
Clay-rich till & $?$ & 100 & 100
\end{tabular}

\section{THE ROLE OF SEDIMENT GRAIN-SIZE IN EROS- ION, DEPOSITION AND GLACIER DYNAMICS}

The tills produced by Pleistocene ice sheets in midlatitude lowlands are predominantly silt-rich, although

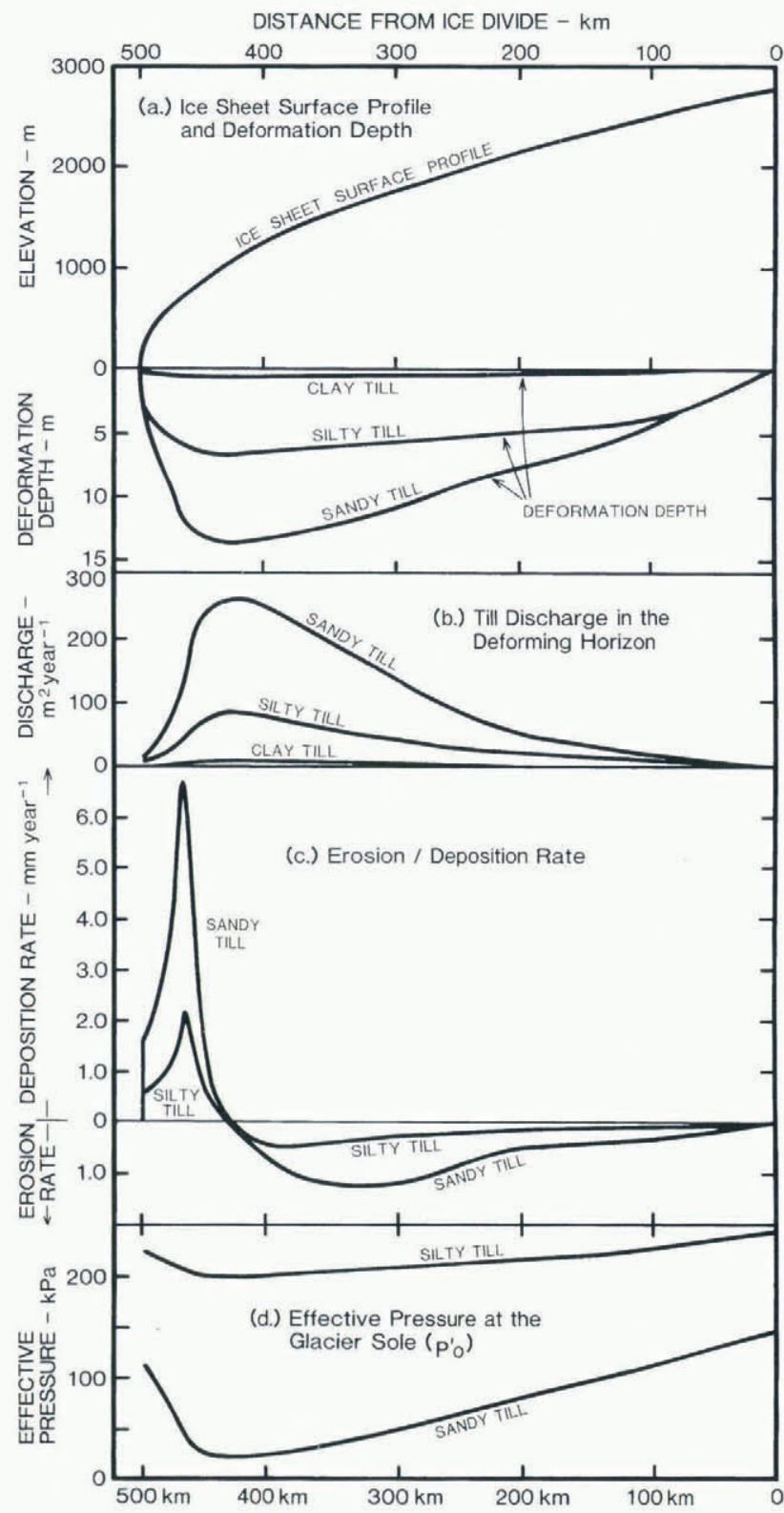

Fïg. 4. Idealized conditions at the bed of a stead)-state ice sheet underlain by a deformable bed for a given ice-flux distribution. Conditions are calculated for clay, sill and sandy lill beds. (a) Thickness of the deforming horizon. (b) The discharge within the deforming horizon. (c) Erosion and deposition rates. (d) Effective pressure at the glacier sole.

some are clay-rich and some sand-rich. Table 1 shows values of flow-law parameters for an Icelandic till (Boulton and Hindmarsh, 1987), a Saalian-age till from the Netherlands Dobbie, 1992) and for a clay-rich till Kamb, 1991). They are formulated for the non-linearly viscous model $\left(\dot{\epsilon}=A\left(\tau^{n} / p^{\prime m}\right)\right)$. Figure 5 illustrates the different responses of granulometrically different tills. The effective pressure at the glacier sole and the velocity profile in each till has been calculated from Equation 8) which would generate the same basal ice velocity Equation (15)) under the same shear stress. The clay till is clearly softest and the sandy till hardest. As a consequence, the deforming-layer thickness needs to be greatest in the sandy till where the strain rate is relatively small and least in the clay till where the strain rate for the 
same stress is very large (Fig. 5). The effective pressure at the top of the sandy till needs to be very small to ensure that the till is soft enough to deform to relatively great depth and also relatively small in the clay till to offset the relatively large cohesion of clay (Fig. 5 ).

The sediment discharge in the deforming horizon is greatest for the sandy till and least for the clay till, which also reflects their erodibility (Fig. 5). This is, however, a

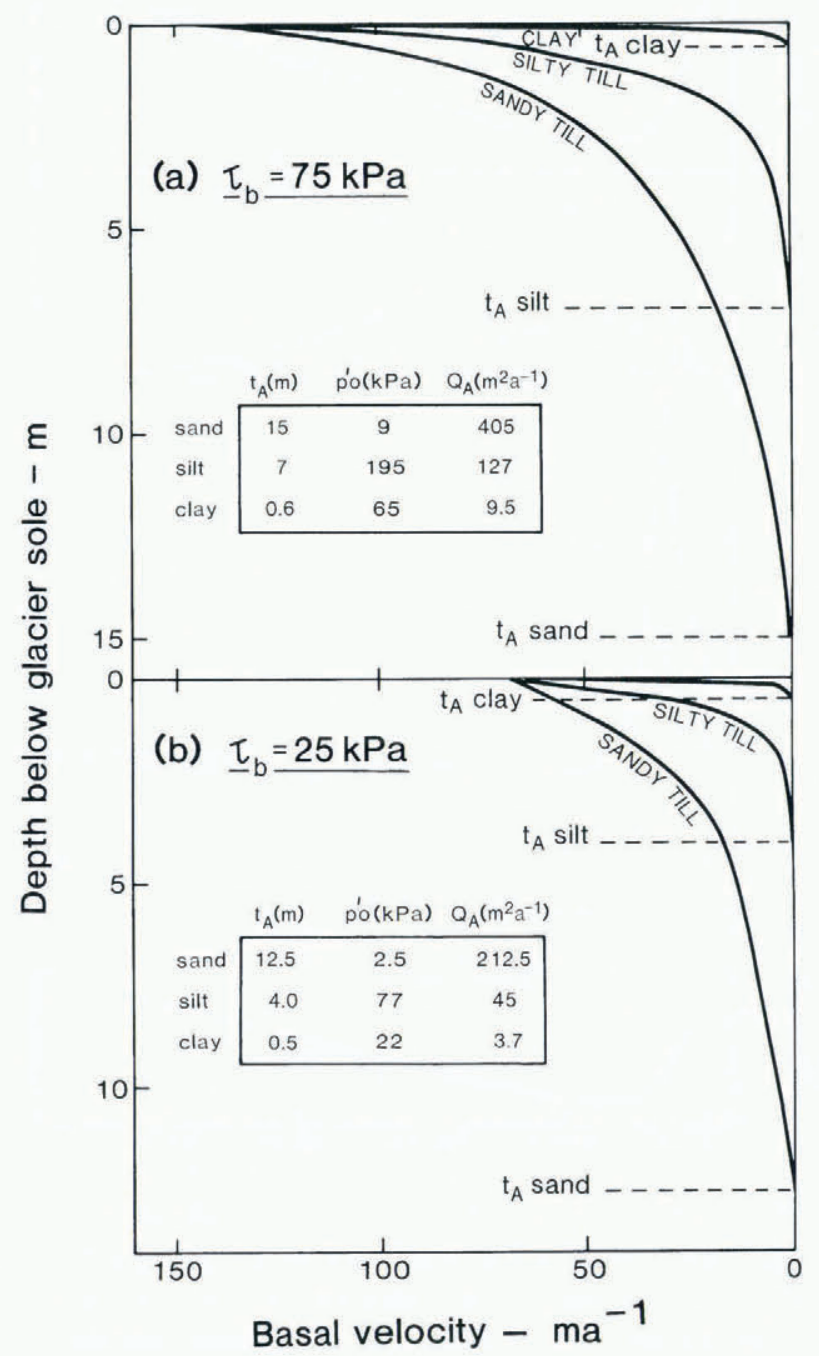

Fig. 5. The influence of gramulometry on till behaviour. It is assumed that the ice flux in the glacier is discharged only as a result of deformation of the bed. We contrast a glacier driven by a relatively high shear stress (a) with one driven by a relatively low shear stress (b). The effective pressure at the ice/bed interface and the thickness of the deforming layer are calculated for three till types (sand-rich, sill-rich, clay-rich) so as to yield basal velocities of $150 \mathrm{ma}^{-1}$ and $70 \mathrm{ma}^{l}$ with shear stresses of $75 \mathrm{kPa}$ and $25 \mathrm{kPa}$, respectively. Deforming layer thickness $\left(t_{\mathrm{A}}\right)$, effective pressure $\left(p_{0}^{\prime}\right)$ and discharge in the deforming layer $\left(Q_{\mathrm{A}}\right)$ for the sand, silt and clay materials are shown in the boxes. To sustain a given velocity, deformation depth and discharge rates (and therefore erosion rates) are greatest for a sand under the smallest values of $p_{0}^{\prime}$. A very small change in effective pressure produces a very large change in strain rate for a clay. In the limit, deformation on a clay surface is analogous to sliding, with a very small discharge and erosion rate. potentially misleading consequence of the assumption that effective pressure is given and ignores the role of sediment permeability in controlling drainage (Boulton and Dobbie, 1993). The sandy till will tend to drain relatively well, leading to high effective pressures, which will inhibit deformation. Shear stresses will therefore build up and the internal flow and sliding components of glacier movement (Fig. 1c) will become larger. Conversely, silty and clayey tills will tend to impede drainage and to seal off any subglacial aquifers so that low effective pressures can be readily maintained. One might therefore expect silty sediments to be the most susceptible to erosion and silty tills to dominate where there is an appropriate sediment supply. Most tills derived from sources where there is a wide range of grain-size available are indeed silt-dominated (Eyles, 1983).

The three different sediment types have very different strain-rate sensitivities to changes in effective pressure. For instance, for a constant shear stress of $40 \mathrm{kPa}$, unit decrease in effective pressure produces changes in strain rate as shown in Table 2.

In response to a perturbation in shear stress or effective pressure, we would expect the sandy till to be most readily stabilizeable through water-pressure adjustments in the subglacial channel system and clay tills to be least stabilizeable. The very low permeability of clays may give them a very slow response time to external water-pressure changes Boulton and Hindmarsh, 1987) and thus be a partial buffer to instability. Although firm conclusions should await a time-dependent analysis, it seems probable that subglacial channel control might permit stable deformation of sand- and silt-rich tills but not of clay-rich tills. Subglacial clays are therefore liable to be a considerable cause of instability, which is reflected, I suggest, by their common occurrence along major planes of tectonic transport in subglacial sediments.

\section{TIME-DEPENDENT PATTERNS OF EROSION AND DEPOSITION PRODUCED DURING GLAC- IAL CYCLES}

Much of the lowland area of Europe and North America which has suffered ice-sheet glaciation during the last million years is covered by soft, deformable sediment and

Table 2. Change in effective pressure required to produce 10-, 100- and 10000-fold increases in strain rate in sand, silt and clay tills, respectively, for a constant shear stress of $40 \mathrm{kPa}$. Righthand column shows strain-rate sensitivity to unit decrease in effective pressure

\begin{tabular}{ccc}
$\begin{array}{c}\text { Change in effective } \\
\text { pressure }\end{array}$ & $\begin{array}{c}\text { Change in } \\
\text { strain rate }\end{array}$ & Sensitivity \\
$\mathrm{kPa}$ & $\mathrm{a}^{-1}$ & $\mathrm{a}^{-1} \mathrm{kPa}^{-1}$ \\
& & \\
\hline $80-20(60)$ & $2-20(18)$ & 0.3 \\
$150-115(35)$ & $2200(198)$ & 5.7 \\
$40-36(4)$ & $0.02-200(200)$ & 50
\end{tabular}


should carry evidence of patterns of erosion and deposition which the theory should be able to explain. However, residual patterns of erosion and deposition will reflect integrated behaviour over complete glacial cycles rather than merely an ice sheet's geological activity during the glacial maximum, as has been assumed in some erosional theories (e.g. White, 1972; Sugden, 1977). It is important therefore that the theory is extended to the time-dependent case. To achieve this, the mass-balance distribution is changed and the function $h(x, t)$ estimated using the continuity equation for ice thickness:

$$
\frac{\delta h}{\delta t}=-\frac{\delta}{\delta x}\left(U_{\mathrm{b}}+\bar{U}_{\mathrm{f}}\right) h+a .
$$

This yields a time-dependent distribution of velocity and shear stress, although the flow field is equivalent to a series of steady states. Values of effective pressure at the ice/bed interface which are compatible with values of basal shear stress and velocity are determined from Equation (15). The erosion/deposition rate is then integrated with respect to time $(t)$.

The time-dependent evolution of an isothermal ice sheet on a horizontal bed driven by a prescribed positive mass budget has been simulated. The equilibrium line was fixed at $60 \mathrm{~km}$ from the terminus. The net annual accumulation rate was constant at $1.0 \mathrm{ma}$. The net annual ablation rate increased linearly from zero at the equilibrium line to a maximum at the terminus. Ice-sheet growth was produced by imposing an average budgetary excess of $45 \%$ on the south side of the ice sheet and $30 \%$ on the northern side. These were switched to deficits of similar proportions after 12000 years in order to produce retreat. The maximum net ablation rate was adjusted to achieve the required budgetary excesses/deficits. From this, the mass-balance velocity through the glacial cycle was calculated and the magnitudes of erosion and deposition determined as described above.

Results are shown in Figure 6 for an ice sheet lying on a horizontal sediment bed of sandy till which is assumed to be at the melting point throughout. Figure 6a $1-5$ shows the progressive evolution of a sediment surface at a series of times during the growth phase of the ice sheet. During expansion, the proximal zone of erosion expands and the distal zone of deposition is progressively displaced outwards as a wave-like form. In the erosional zone, the $\mathrm{A} / \mathrm{B}$ décollement descends. In the depositional zone, the $\mathrm{A} / \mathrm{B}$ plane migrates upwards as deposition proceeds but is then succeeded by downward migration of the $\mathrm{A} / \mathrm{B}$ plane as the erosional zone expands. During retreat (Fig. 6b, 5 $10)$, further erosion occurs in the proximal zone but, as the distal zone of deposition withdraws over the eroded surface, a retreat phase till is deposited.

The pattern of erosion and deposition during the whole cycle is illustrated in Figure 7a by the time space envelope for a mid-latitude ice sheet expanding from an initial nucleation point, both to the north, where it will be limited by moisture starvation and the ocean margin, and to the south, where it will be limited by high surfacemelting rates. The ice sheet then contracts to the area in which it first began to develop. The mass-balance distribution was adjusted to produce a temporally symmetrical cycle. During an ice sheet's decay phase,

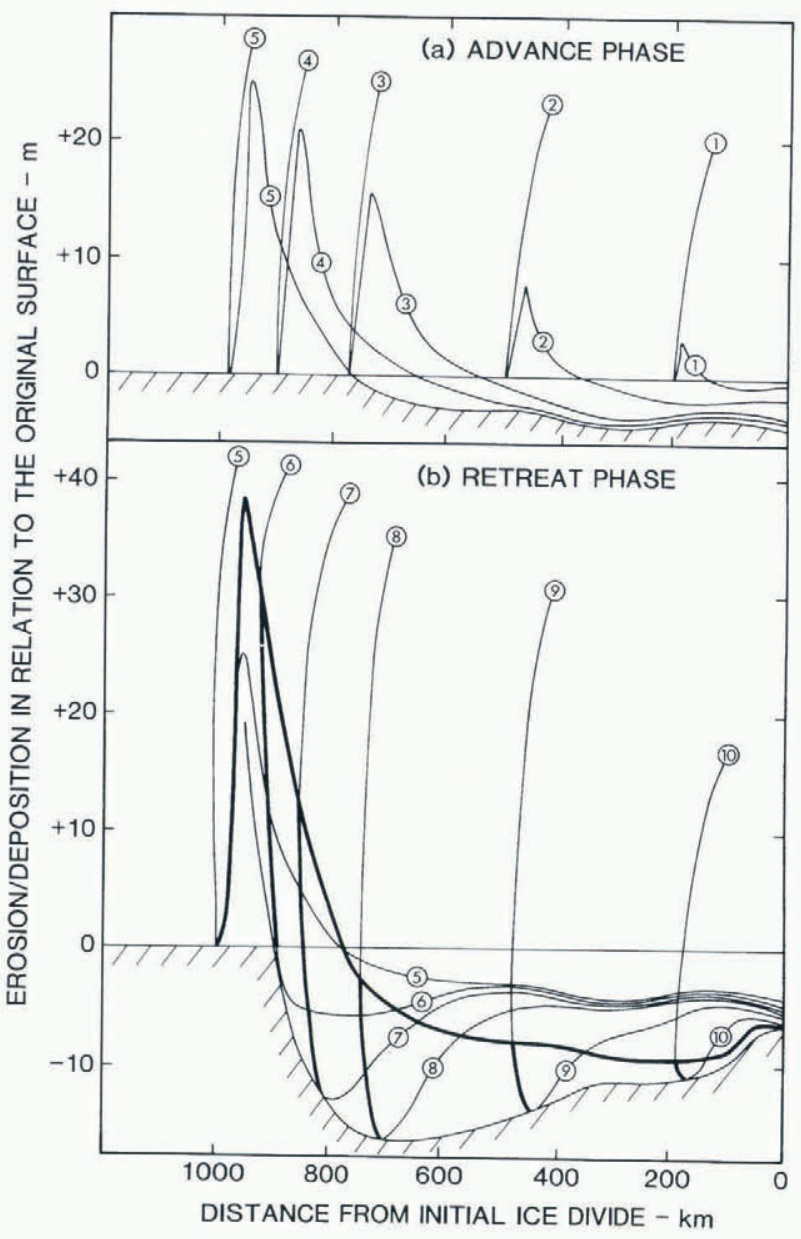

Fig. 6. Progressive evolution of the sediment bed of an ice sheet during its advance and retreal phases. (a) 15 show stages in the evolution of the bed and contemporary ice margins during the advance phase. The horizontal line shows the original position of the pre-glacial surface, and the shaded surface the position of the bed at the end of the advance phase. Deformation produces erosion and lowering of the bed in the up-glacier zone, and deposition and elevation of the bed in the terminal zone. A wave of deposition sweeps outwards beneath the advancing glacier, followed by progressive extension of the erosional zone. Any point bing initially beyond the glacier is first covered by an increasing lill thickness in the depositional zone. Subsequent erosion first thins the till and then erodes benealh the original surface. (b) The further evolution of the bed during ice-sheel retreal. The initial form of the uneroded substratum bed is shown by 5 and the final form by 10 . Thick lines show where the bed is made of deposited till al each slage of retreal. In this model, the retreat phase is laken to be longer than the advance phase, resulting in grealer net erosion during retreat.

the zones of erosion and deposition contract and, as the depositional zone retreats over a previously eroded surface, a capping of till accumulates.

The histories of a series of sites $(\mathrm{A}-\mathrm{I})$ are followed through the glacial cycle as zones of erosion and deposition expand and contract. In the inner zone C$\mathrm{H}$ ), the initial phase of depositon is short. In the succeeding erosional phase, the pre-existing till is soon removed and erosion cuts down into hitherto undeformed 


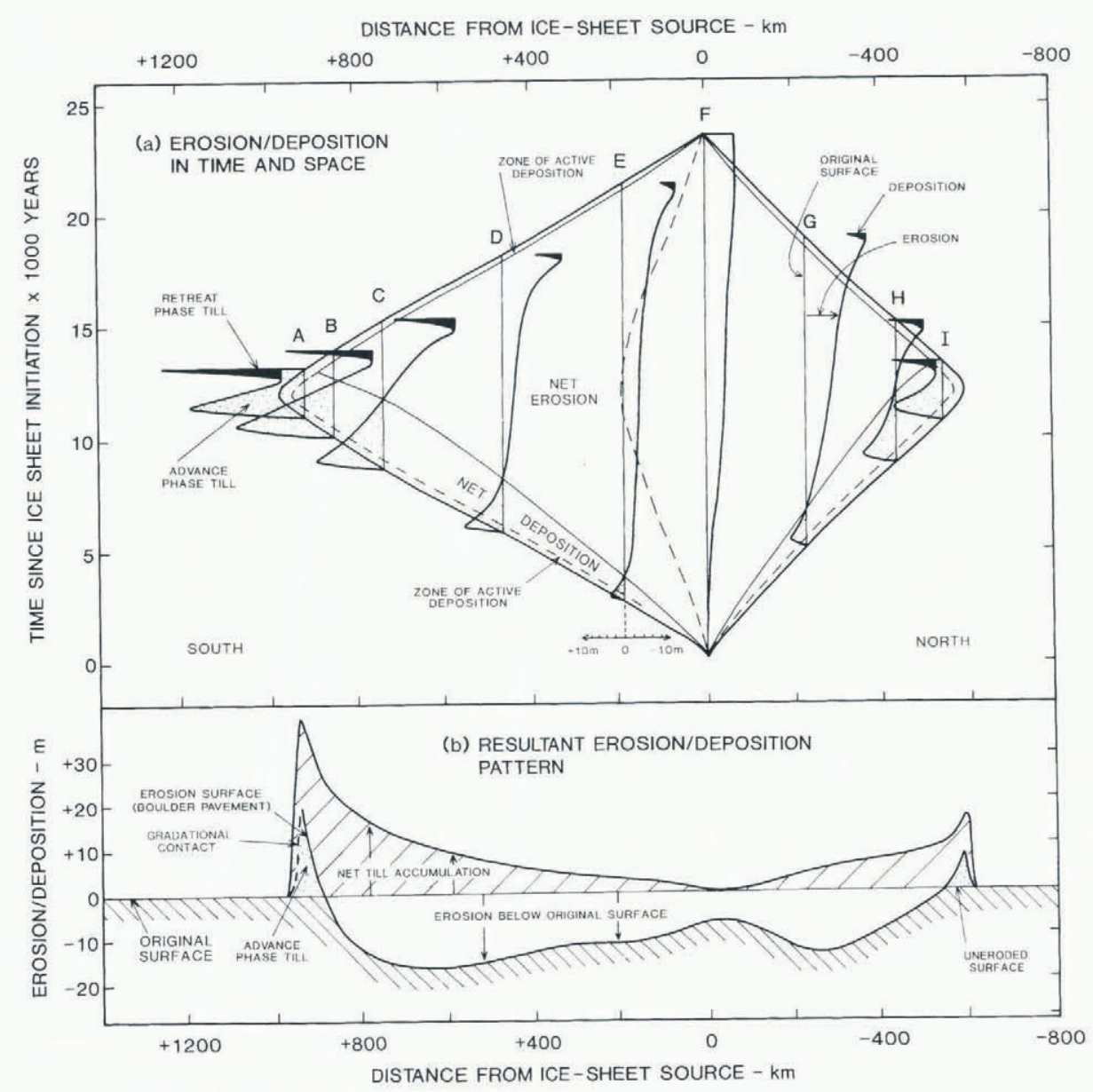

Fig. 7. (a) Time-space envelope of an ice sheet during a simple glacial cycle and the history of erosion and deposition at specific siles $(A-I)$. At these siles, vertical lines show the original surface and a further line shows its erosional/depositional evolution. At $B-H$, till is first deposited as the glacier over-rides the sites. In the succeeding erosional zone, the advancephase till is removed until erosion bites down beneath the original substratum, and a final retreat-phase till is then deposited on the eroded surface. At A and I, deposition during the retreat phase recommences before all the advance-phase till has been eroded, resulting in two tills with an intervening erosion surface (possibly marked by a boulder pavement). The extreme northern and southern marginal zones al the maximum lie entirely in the depositional zone, and so till deposition is continuous, though the rate varies. If the ice divide were stationary, no erosion would occur beneath it. Erosion here only occurs because of the divide shift. (b) The resultant pattern of erosion and deposition at the end of the glacial cycle. There are four principal zones: an ice-divide zone of lille erosion and thin retreat-phase tills; an intermediale zone of strong erosion and thicker retreal-phase tills; a zone of thickest till, resting on an uneroded substratum, comprising a lower, advance-phase till, separated by an erosion surface from the retreat-phase till; an outer zone of thinner till in which the advance-phase till grades upwards into the retreat-phase till.

sediments. As the glacier expands further, the erosion rate decreases, increases again after the glacial maximum and finally diminishes before it gives way to a phase of deposition just before deglaciation of the site. At sites A and I, the erosional phase is not long enough for the advance-phase till to be entirely removed before deposition recommences during glacier retreat, producing two till units with an intervening erosion surface. At these sites there is no erosion of preglacial beds. Very close to the overall terminus, there is no cessation of deposition but the deposition rate does vary, being least during the phase of most extensive glaciation.

The net result of this cycle of erosional and depositional activity is shown in Figure 7 b. Four major zones are identified:

Zone 1. The ice-divide zone, with slight erosion and a thin till deposited during the retreat phase.
Zone 2. A zone of strong erosion with a till derived from the retreat phase only.

Zone 3. A zone of no erosion of preglacial beds overlain by a thick till sequence containing both advance- and retreat-phase tills but with an intervening erosional interface.

Zone 4. A zone of no erosion of preglacial beds overlain by a thick till sequence continuously deposited throughout the local glacial cycle.

Because of the greater expansion to the south compared with the north, the ice divide also migrates to the south during expansion and returns north to its original position during decay. It is important to note that, if the ice divide in an ice sheet were to remain stationary through the whole glacial cycle, there would be neither significant erosion nor deposition beneath it, as the horizontal ice 
velocity tends to zero beneath the divide. Only movement of the divide through the cycle, as a consequence of a changing centre of mass which reflects ice-sheet/atmosphere interaction Boulton and Clark, 1990) ensures that erosion and till deposition will take place in the divide zone.

The predictions of the theory are contrary to the views of White 1972) who argued that deep erosion is concentrated beneath the central parts of ice sheets.

Figure 8 shows a model run in which an average $30 \%$ mass-balance excess during ice-sheet build-up on its southern flank is sustained for 20000 years and an

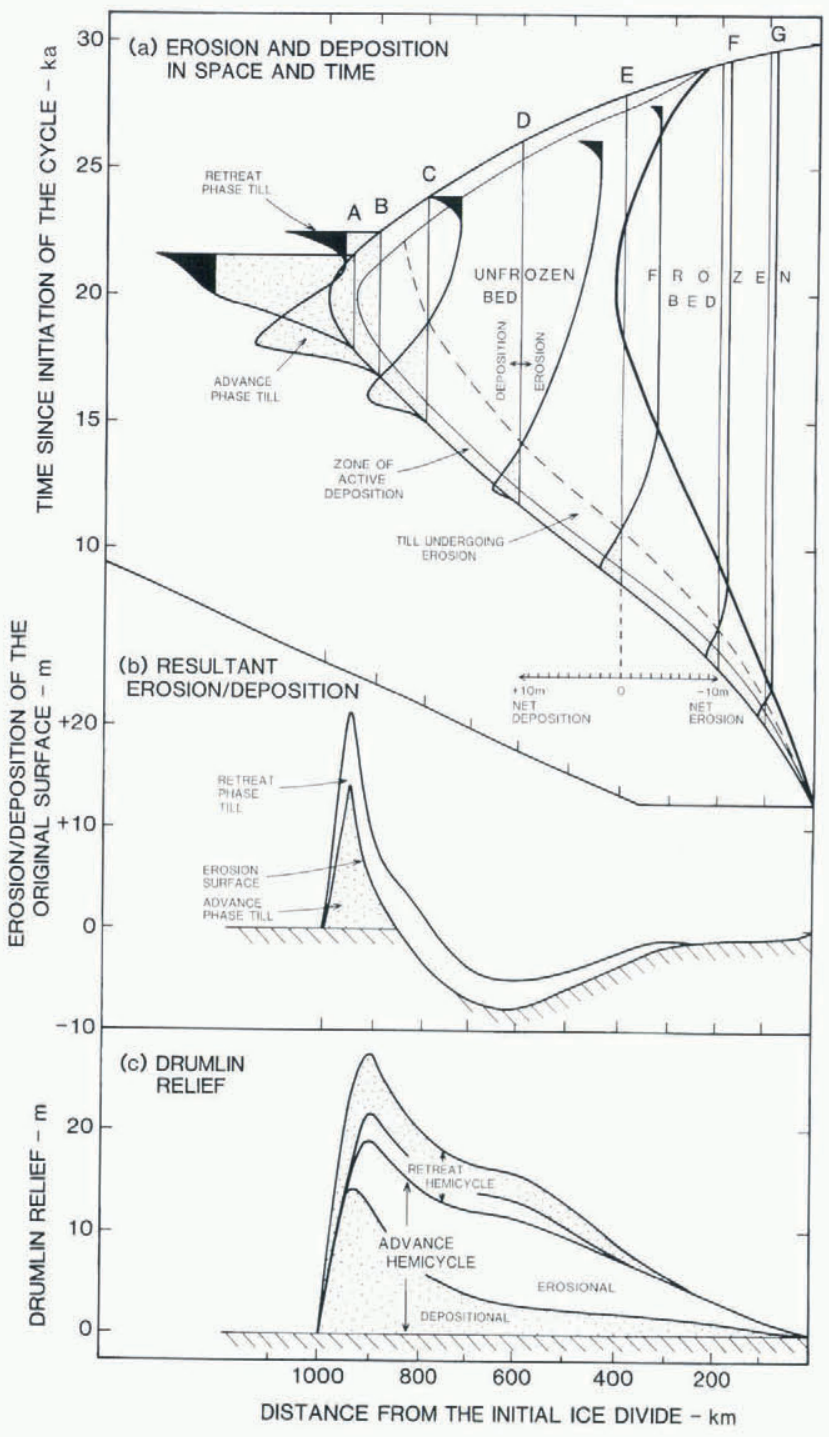

Figg. 8. (a) A diagram similar to Fïgure $7 a$ bul showing an asymmetric cycle for a semi-span, in which the period of build-up is longer than the period of decay, and in which there is a frozen-bed zone beneath the divide area. Some erosion occurs in the divide zone during build-up but no till is deposited there during retreal as the bed remains frozen during deglaciation. (b) The resultant paltern of erosion and deposition. (c) The polential relief of drumlins assuming an inexhauslible sediment supply and uniform bed materials. It showes phases of deposition then erosion during the advance hemi-cycle and erosion then deposition during the retreat hemi-cycle. average deficit of $36 \%$ during retreat. This produces an asymmetric pattern of growth and decay similar to the presumed normal pattern during late Quaternary glacial periods. Hindmarsh and others (1989) have suggested that mid-latitude ice sheets in Europe and North America had a broad ice-divide zone and a narrow terminal zone where basal temperatures were below the melting point, and a broad intervening zone in which melting occurred. Boulton and Payne (1992) suggested that as much as $800 \mathrm{~km}$ on the southern flank of the European ice sheet at the glacial maximum underwent basal melting, beyond a $200 \mathrm{~km}$ zone beneath the divide in which temperatures were below the melting point. Moreover, they showed that the distribution of basal melting/freezing was relatively insensitive to precise values of surface temper-ature and mass balance, provided that the atmospheric lapse rate lay within the range of modern values. The basal melting/freezing distribution for the glacial cycle shown in Figure $8 \mathrm{a}$ is based on typical patterns produced by the Boulton and Payne model. It shows temperate basal conditions during the advance phase in the outer part of the ice sheet, extending to over half the ice-sheet span. During the decay phase, however, retreat of the ice front is much more rapid than retreat of the temperate/cold thermal boundary Boulton and Payne, 1992, so that in the late stages the whole of the base of the ice sheet lies below the melting point.

The importance of thermal regime lies in the assumption that there will be no sliding motion between a glacier sole and bedrock where the interface is below the melting point Goldthwait, 1960), because of the large shear strength of such a contact Jellinek, 1959). I assume that this applies not only to bedrock but also to frozen sediment. It is also assumed that no erosion will occur at such a contact, apart from large-scale bedrock detachment Mackay, 1959; Boulton, 1974). Several major geomorphological contrasts have been explained as a consequence of suppression of erosion by frozen-bed conditions Sugden, 1977; Boulton, 1979; Andrews and others, 1985; Kleman, 1990; Lagerbäck, 1990 ).

Inclusion of the basal thermal regime generates an additional effect (Fig. 8b). In the internal zone, erosion occurs and till accumulates during the early phase of growth when the bed is unfrozen but extension of the frozen zone inhibits further erosion and leads to preservation of early tills and erosional features. These are not subsequently eroded, as the internal zone remains a zone of basal freezing until deglaciation.

\section{SEDIMENTS OF THE A HORIZON AS TILLS}

Figure 5 suggests that sediments in the deforming $\mathrm{A}$ horizon can readily attain velocities in excess of $100 \mathrm{~m} \mathrm{a}^{-1}$ and strain rates in excess of 50-100 a ${ }^{\prime}$ under relatively low shear stresses. Velocities averaged over periods of days to weeks in the $\mathrm{A}$ horizon beneath Breidamerkurjökull, Iceland, vary from 10 to $64 \mathrm{ma}$ !

Observations at Breidamerkurjökull Boulton, 1987) show that local inhomogeneities and high shear strain rates within the $\mathrm{A}$ horizon generate folding episodes. If these episodes are frequent, they have the capacity to mix 
thoroughly and homogenize the sediment, leaving no markers by which folding may be recognized. I suggest that sediment deposited from this horizon should be regarded as a primary sediment produced by ice rather than as a pre-existing sediment which has merely been tectonized. Boulton (1987) suggested that the term deformation till should be applied to it.

Ehlers and others (1991) commented that the relative rarity of deformational structures at the base of tills or in sub-till sediments in the area occupied by the European ice sheet implies that deformation tills are unlikely to be the dominant till type in Europe. Such conclusions reflect misunderstanding of the sedimentary consequences of the deformation process. Consider the base of the deforming horizon in the erosional zone. As the A/B plane descends, hitherto undeformed sediment is drawn into the $\mathrm{A}$ horizon flow. This may be on a grain-by-grain basis or as thin cohering layers. The $\mathrm{A} / \mathrm{B}$ plane may, however, be rough or the sediment drawn into the flow may be stiffer than the deforming sediment around it, in both of which cases stress concentrations will develop and folding will occur and, if sufficiently frequent, will eventually homogenize the sediment. Eroded sediment will be transported in the A horizon and, at some distance from its source, will eventually be deposited as till. During transport we expect shear strain rates (Fig. 5) of the order of $10-100 \mathrm{a}^{-1}$. Such rates would reduce a $1 \mathrm{~m}$ high vertical structure produced by folding during incorporation to a dip of $0.5-0.05^{\circ}$ after only 2 years of transport and during the same period would attenuate it horizontally by 10 $100 \mathrm{~m}$. Only if the sediment is "frozen" by deposition shortly after folding of an unhomogenized sediment will folds with steep limbs survive. Deposition after further folding and attenuation will tend to produce the commonly found laminated tills, and deposition after longer transport will produce homogenized tills Boulton, 1987 ).

It is suggested that three basic deformation till facies can be identified which reflect progressively greater incremental strain. They are:

Tills with folds which reflect incorporation of local materials into the till, which will only be preserved if the incremental strain is very small and when deposition occurs shortly after the folding event.

Laminated tills in which the laminations reflect repeated refolding and attenuation of original sedimentary layering.

Massive tills which have been homogenized by repeated folding and attenuation.

In general, the more obvious the tectonic structures, the less the incremental deformation. Moreover, a consequence of long-term erosion of a surface by deformational lowering of the $\mathrm{A} / \mathrm{B}$ plane will be progressive smoothing of the surface. Protruberances on an originally rough surface will tend to concentrate stress around them, resulting in their removal. Deposition of till will eventually occur on this surface. Mature deformation tills will therefore tend to be massive, lie on smooth planar surfaces below which there will be few signs of tectonic disturbance, as they will tend to protect underlying sediments from deformation. A till overlying a sediment with few or no deformation structures is much easier to understand if the till is a deformation till rather than a lodgement or melt-out till. A deformation till is a means of absorbing strain. As a soft deforming layer, it acts as buffer between the stiffer ice and underlying sediment, thus minimizing disruption in the sediment. In the case of a lodgement or melt-out till, an ice surface has, at some stage, flowed directly over the underlying sediment, generating a relatively large shear stress at the interface, and is thus much more likely to generate deformation in the sediment.

\section{THE STRENGTH OF LARGE-SCALE DRIFT LINEATIONS (DRUMLINS) FORMED BY SUB- GLACIAL SEDIMENT DEFORMATION}

The theory developed above implicitly asumes that the processes leading to large-scale patterns of erosion and deposition operate in two dimensions, in a plane parallel to the direction of flow. Whilst I believe that this is a reasonable assumption in relation to the average thickness of tills and the average depth of erosion, there are other features such as drumlins, which have been individually fashioned by relatively small-scale three-dimensional flows. It is suggested Boulton, 1987) that there are two drumlin end members:

Erosional drumlins in which pre-existing sedimentary sequences have been eroded to produce typical streamlined ridge forms.

Depositional drumlins in which the form of the drumlin has been built up from sediments which have accumulated subglacially.

Boulton (1987) has discussed the way in which subglacial deformation of sediments could lead to the formation of both end members, either by deformational erosion of soft sediments around a relatively resistant core or the deposition of hitherto deforming sediment around a resistant core. Some drumlins appear to combine both erosional and depositional characteristics and some younger drumlins appear to be superimposed on older forms (Rose and Letzer, 1977).

I suggest that the relief and length of drumlins is likely to be related to the net intensity and duration of erosional/depositional processes, and that a drumlin is most likely to be deeply incised by local three-dimensional flow if the ice has a large capacity to create relief by either erosion or deposition. I suggest therefore that the rate of relief formation, $(\dot{R})$, whether by erosion or deposition, will simply be given, irrespective of sign by:

$$
\dot{R}=\int_{T_{\mathrm{a}}}^{T_{\mathrm{r}}}|\dot{E}| \delta t
$$

where $T_{\mathrm{a}}$ and $T_{\mathrm{r}}$ are the times at which a glacier margin advances over and retreats from a site, respectively, and the magnitude $|\dot{E}|$ is given by Equation (10).

Whether these forms are primarly erosional or depositional will be determined by the net sign of the integral of $\dot{E}$. Figure $8 c$ shows the intensity of lineation produced during the glacial cycle modelled in Figure 
8a. There is a low lineation strength in the area of initial ice-sheet nucleation and final decay but lineation strength increases outwards, reaching a first maximum about $100200 \mathrm{~km}$ from the maximum extent of glaciation, and a second maximum very close to the maximum extent. The first maximum corresponds to the zone of strongest net erosion and the second maximum to the zone of strongest net deposition. Three broad zones of different lineation character and strength are predicted:

A broad internal zone comprising a large part of the area occupied by the ice sheet in which erosional drumlins dominate, although late-phase depositional forms may be superimposed on them. Where activity is suppressed during the retreat phase by basal freezing, only advance-phase drumlins will occur.

An intermediate zone in which we expect strong erosional lineations to be overlain by strong depositional features.

An outer zone in which depositional lineations dominate.

It should be stressed, however, that these conclusions reflect the nature of the specific glacial cycle modelled here rather than a prediction specific to any other cycle. Observed spatial patterns should be related to the specific characteristics of the cycle which produced them.

\section{FACTORS CONTROLLING SMALL-SCALE PATTERNS OF EROSION AND DEPOSITION}

The large-scale patterns inferred in preceding sections represent the outcome of an idealized glacial cycle for a two-dimensional ice sheet flowing over a horizontal bed of uniform geology. As developed above, the theory does not take into account more complex local patterns which arise as a consequence of:

Complex three-dimensional variations in ice-sheet dynamic regime and extent.

Variations in bed geology and topography.

The theory should not be used, therefore, to interpret the significance of small-scale features, except where these can be shown to be part of a larger regional pattern. Some of the smaller-scale patterns which may arise as a consequence of more complex temporal and spatial variation in ice-sheet dynamic properties are illustrated below.

\section{Temporal changes}

Temporal variations in ice-sheet extent more complex than those shown in Figures 7 and 8 may produce more complex patterns of erosion, deposition and lineation. The nature of this complexity is illustrated schematically in Figure 9 by an example in which a period of standstill interrupts the advance of an ice sheet to its maximum and one in which a re-advance interrupts the retreat from the maximum.
In the first case (Fig. 9a and b), the thickness of the advance-phase till deposited during standstill is such that subsequent erosion during recommenced advance is not enough to remove it. In the second case (Fig. 9c and d), tills deposited during the initial advance (1A) and retreat (IR) are not entirely removed during the succeeding readvance phase $(2 \mathrm{~A} / \mathrm{R})$. The extent to which these earlier tills are removed will depend on the duration and intensity of the erosional phase. Elements of all may survive or all may be removed. Patterns of conformity and unconformity will be similar to those shown in Figures $7 \mathrm{~b}$ and 17 .

\section{Spatial variations}

Although the theory has been applied above to twodimensional flowline transects, it can be readily applied to three dimensions to investigate effects which are not radially symmetrical. For instance, it has been shown that Pleistocene ice sheets underwent major shifts in the locations of their divides through glacial cycles Boulton and Clark, 1989). Shifts of the quasi-radial patterns centred on divides will produce predictable displacements in the patterns of erosion and deposition.

Modern ice sheets show well-defined ice streams which play an important dynamic role and are characterized by velocities which are substantially higher than in interstream ridges. There is strong evidence that large ice streams also occurred in Pleistocene mid-latitude ice sheets (e.g. Punkari, 1980). A distal displacement of erosional and depositional zones would be expected in an ice stream terminating on land together with intensification of erosion and deposition compared with the flanking, more sluggish ice.

Ice streams are also commonly found flowing into the sea, where they are produced by enhanced draw-down into deeper offshore waters (Hughes, 1977). They exhibit accelerating flow towards a calving terminus. The theory suggests that this accelerating flow will ensure that net erosion occurs up to the terminus so that all transported sediment is discharged into the marine environment, producing both grounding-line "till deltas" (Alley and others, 1989 and debris flows.

Implications of the theory for erosion/deposition beneath marine ice streams have been described by Boulton (1990).

\section{Effects of bed geology}

The rheological and integrated hydrogeological properties of bed sediments are fundamental properties which influence the erosional and depositional effects of glaciation. These properties are not independent. The strain rate for a given shear stress tends to be larger for fine-grained, low-permeability sediments than for coarsegrained, high-permeability sediments under the same effective stress conditions.

The bed may be composed of any combination of lithified material, generally undeformable under glacial stresses, and unlithified, potentially deformable sediment. The threshold for deformation of unlithified sediment and the deformational response to stress will depend upon the efficiency of subglacial drainage, which also helps 
(a.)

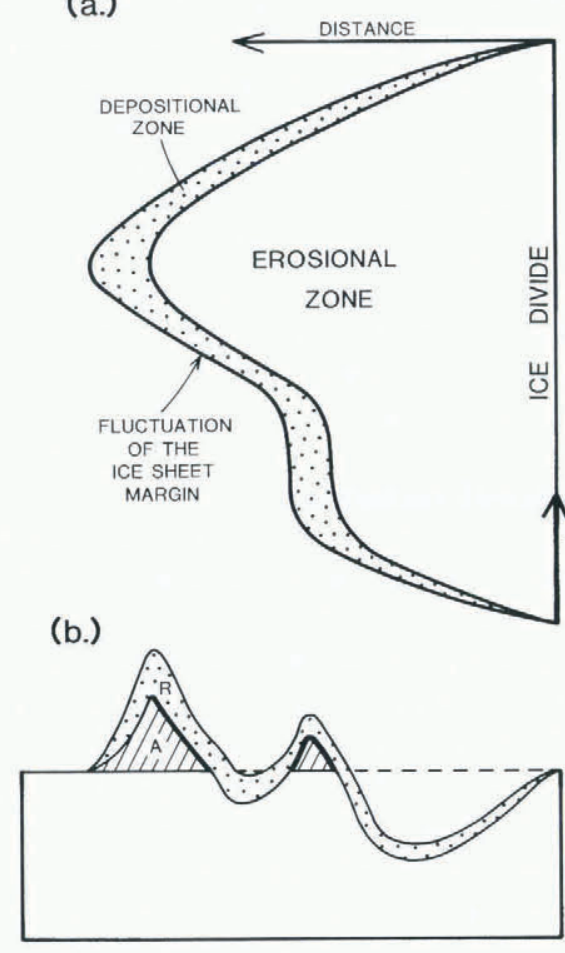

VIII ADVANCE-PHASE TILL

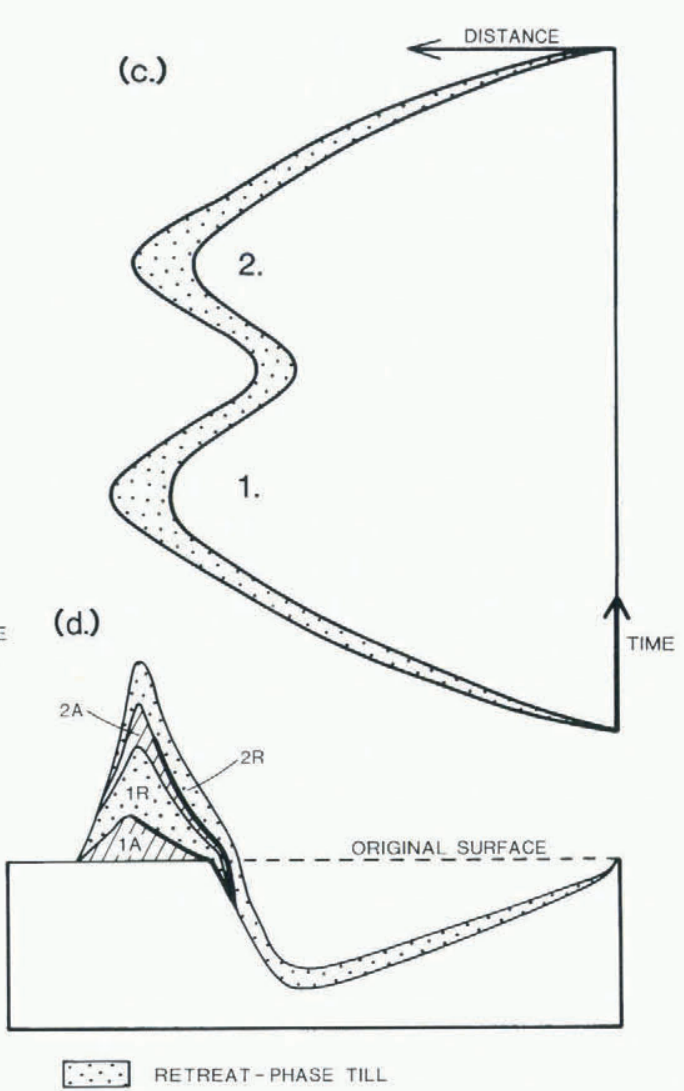

Fig. 9. A schematic diagram showing till sequences generated by more complex pallerns of ice-sheet fluctuation. Advancephase tills are shaded, retreat-phase tills are stippled and erosion surfaces within the till sequence are marked by heavy lines. $(a-b)$ An ice sheet with a prolonged period of standstill during advance. A substantial thickness of till is deposited in the terminal zone during the standstill, which is not entirely removed by erosion during the ice sheet's subsequent advance to its maximum. (c-d) Stacked till unils with intervening erosion surfaces (potentially marked by boulder pavements) produced by re-advance (2) of an ice sheel after initial retreal from its maximum (1).

determine effective pressures. Three extreme states can be identified:

(a) The glacier is underlain by impermeable bedrock; the bed is rigid and passive; dynamics are icecontrolled; conduits occur at the glacier/bed interface.

(b) The glacier is underlain by thick, coarse-grained, permeable unlithified sediments; high effective pressure occurs at the bed; there is no sediment deformation; the bed is rigid and passive; dynamics are ice-controlled; no conduits occur at the glacier/bed interface.

(c) Fine-grained impermeable sediments block drainage; conduits develop at the glacier/bed interface; sediments deform; glacier dynamics are strongly influenced by bed deformation.

The property which discriminates between bed types (b) and (c) is their capacity to discharge water by intergranular flow under a given pressure gradient. Boulton and Dobbie (1993) have shown that, apart from beneath small glaciers, subglacial sediment transmissibilities greater than the order of $10^{2} \mathrm{~m}^{2} \mathrm{a}^{1}$ will tend to favour bed response (b) rather than (c). Such values occur, for instance, in the widespread Quaternary aquifer in The Netherlands underlying the
Saalian tills.

Few if any glacier beds are likely to conform entirely to any one of these models; most are likely to be a complex mosaic. Where a significant proportion of the bed is deformable, the bed mosaic will be time-dependent. The contrasting rheologies of the components of this mosaic will tend to produce a complex pattern of strain rates, producing sedimentary mixing. This will lead towards homogenization of the deforming mass, producing the tills of relatively uniform lithological and, presumably, rheological properties typical of lowland areas (Perrin and others, 1979). Thus, where a deformable subglacial bed is composed of more than one lithology, the process of deformation may re-organize bed lithologies in a way which may fundamentally change the distribution of geohydrological and rheological properties.

The greater erodibility of fine-grained sediments and their capacity to seal off underlying coarsegrained permeable beds suggests that even relatively infrequent sources of fine-grained sediments can be the dominant source for tills in lowland areas, and explains why fine-grained tills far from their source frequently overlie extensive sandy beds. Rappol and others (1989), for instance, showed that Saalian tills in The Netherlands, which overlie a thick sandy aquifer of high transmissibility, have a clayey matrix component which may be largely derived from the Baltic, about $500 \mathrm{~km}$ distant. 


\section{DISPERSAL OF BED MATERIALS AND THE COMPOSITION OF TILL}

It has been suggested above that the constituents of the upper part of the deforming till will tend to be continually homogenized by folding. The mean transport velocity $\left(\bar{U}_{t}\right)$ of this homogenized till mass will be:

$$
\bar{U}_{1}=\frac{Q_{\mathrm{A}}}{z_{\mathrm{A}}}
$$

where $Q_{\mathrm{A}}$ is given by Equation $(9)$ and $z_{\mathrm{A}}$ by Equation (5).

The mean velocity of a deforming subglacial sediment package at any point along a flowline at a given time is given by Equation (18). The net displacement $(d)$ of the sediment package through time from any starting point is:

$$
d=\int_{t_{1}}^{t_{11}} \bar{U} \delta t .
$$

Using this, the displacement of sediment packages through time has been determined from the deformation velocities calculated for Figure 7 and is plotted as time distance trajectories of subglacial sediment packages in Figure 10. Erosion rates determined for the model in Figure 7 have also been plotted in the same space. Thus, it is possible to determine both the amount of sediment progressively acquired by a moving sediment package in the erosional zone and the relative amounts of material picked up from different sources. Note that the increasing discharge in the erosional zone permits a sediment package continuously to acquire new material, so that the package is continuously changing its composition. When it moves into the depositional zone, however, it begins to lose material and does not further change composition.

Figure 1la shows the composition of a sediment package as it moves along the time distance trajectory $B_{\mathrm{A}}$ in Figure 10. A particular trajectory is unique to a particular package; a later package will move along a different trajectory.) Lithologies derived from between 200 and $400 \mathrm{~km}$ appear to be over-represented. This is because, between 200 and $400 \mathrm{~km}$, the trajectory lies in a zone of high erosion rate for a relatively long period. Subsequently, the product of erosion rate and residence time diminishes, until it begins to increase strongly in the terminal zone, where locally derived lithologies dominate. In the theory, it is only the packages in the local lithologydominated terminal part of the trajectory which are deposited as till. Different trajectories in the time distance field show systematically different patterns of evolution. reflecting the dynamic evolution of the system.

Figure $11 \mathrm{~b}$ shows the changing composition of successive sediment packages as they move over point A in Figure 10 between 11.5 and $15.5 \mathrm{k}$ model years. Note that in the earlier part of this period, far-travelled debris is relatively more important than later, when the site is much nearer the ice margin. The lithological compositon at $15.5 \mathrm{ka}$ represents the lithology over the site immed-

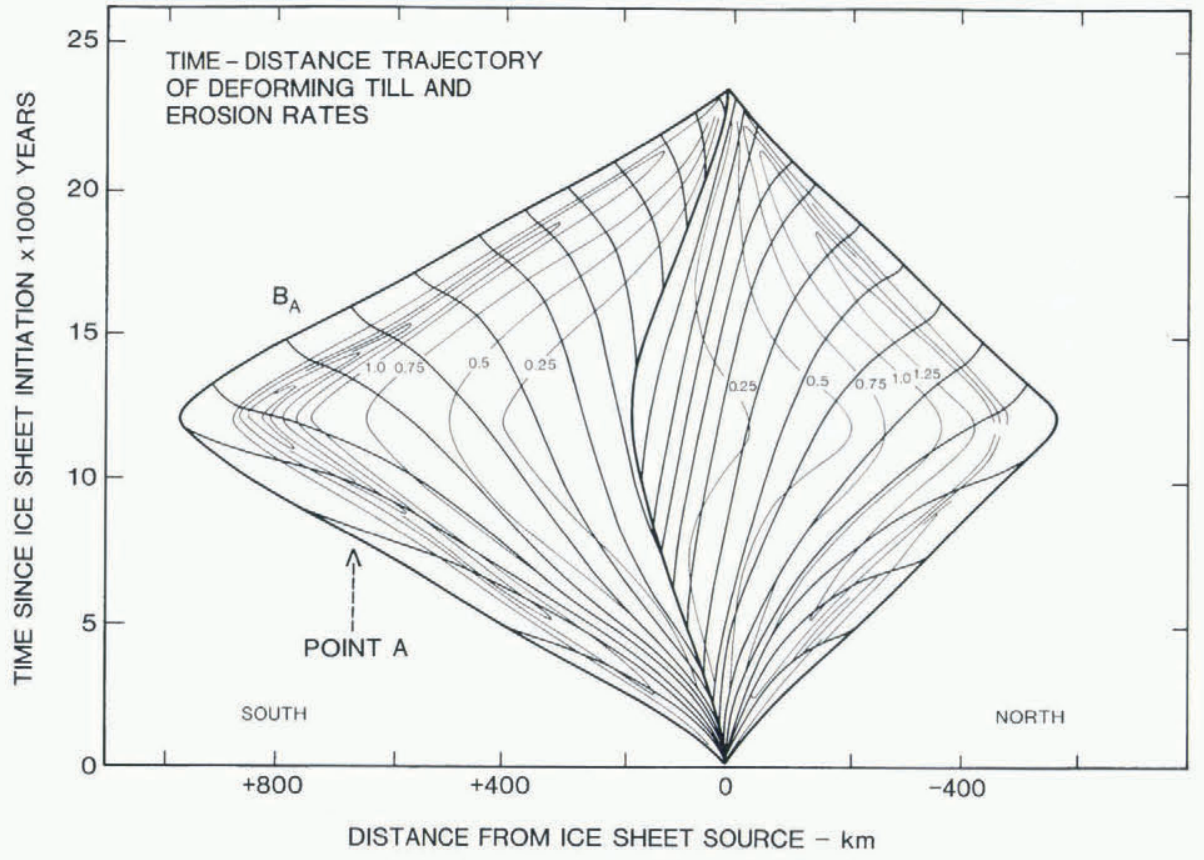

Fig. 10. Time distance trajectories (heavy lines) of till constituents through the glacial cycle shown in Fïgure 7. It assumes that the deforming layer is perfectly mixed by frequent folding and that the time distance trajectory of the constituents moves as a package whose velocity is given by sediment discharge divided by deforming-layer thickness. It also shows erosion rates (lighter lines) in millimetres per year. As sediment packages move along their trajectory in the erosional zone, they continuously acquire more sediment, al a rate given by the erosion rate. They thus progressively lose mass as deposition occurs. The composition of till being deposited from a particular package trajectory will be constant. If the bed is frozen beneath the ice-divide zone, no material will be derived from the frozen zone. Figure lla shows the changing composition of the sediment package moving along the trajectory $B_{\mathrm{A}}$ (the one terminating al $800 \mathrm{~km}$ ) and Figure $11 \mathrm{~b}$ shows the changing composition of deforming material moving over point A (located al $675 \mathrm{~km}$ ) through time. 

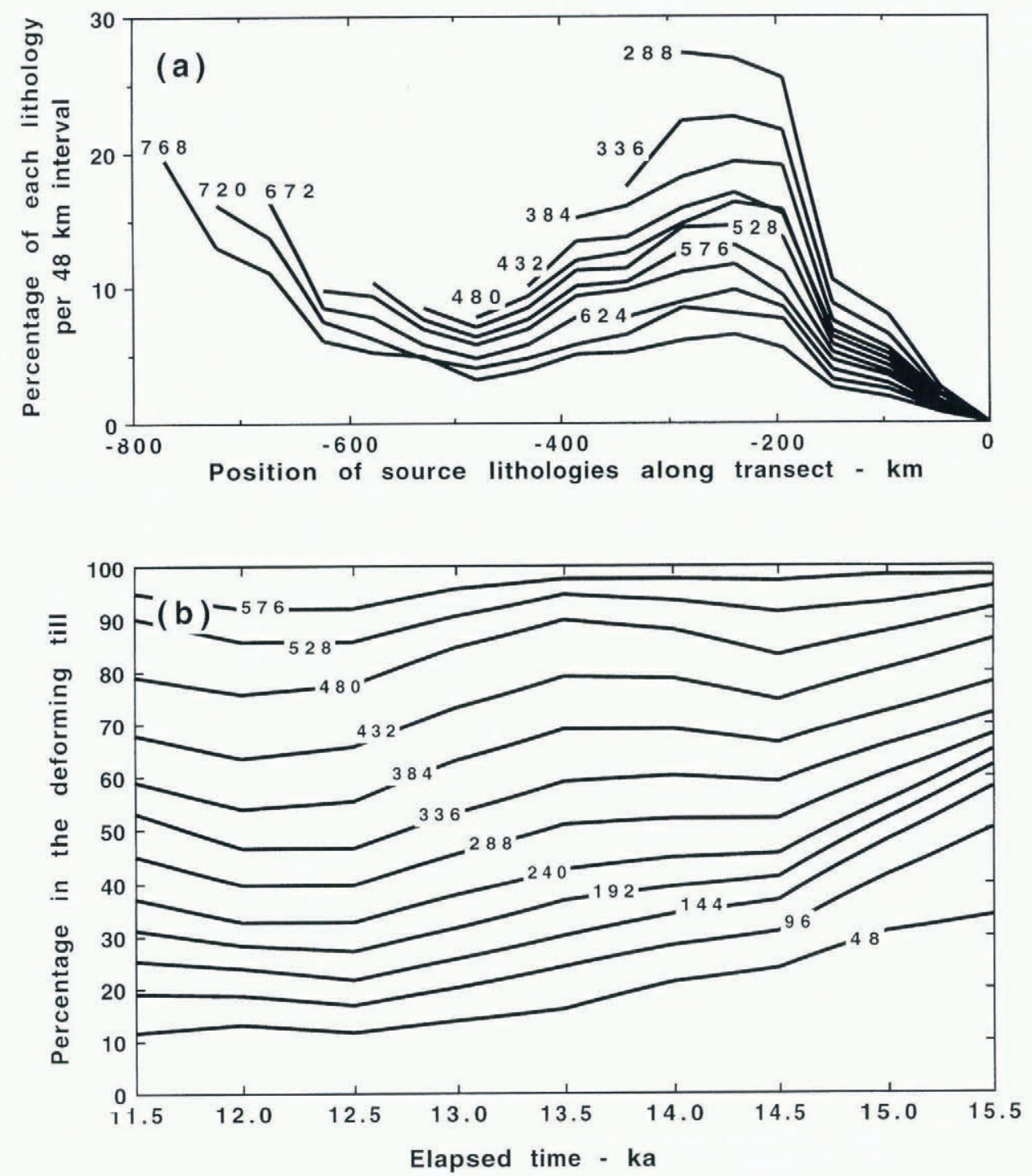

Fig. 11. (a) The changing lithological composition of a single deforming-sediment package traced along its time/distance trajectory $\left(B_{A}\right.$ in Figure 10). The curves show the proportion of each lithology in relation to the position of the source lithology in $\mathrm{km}$ along the transect (horizontal axis). The distance along the transect at which composition is sampled is marked on each curve. The peaks reflect zones of high erosion rates. (b) The changing lithological composition of successive deforming-sediment packages as they pass over point A in Figure 10. The plolled lines show the percentage of debris derived from a distance in $\mathrm{km}$ less than that shown on the lines. For instance, the proportion of material derived from a distance less than $96 \mathrm{~km}$ from point $A$ increases from $20 \%$ al $11.5-13 \mathrm{ka} 10.50 \%$ at $15.5 \mathrm{ka}$.

iately before deposition begins there. The superimposition of material from successive trajectories, which builds up a till sequence with a vertical lithological gradient, is described later (Fig. 14).

Figure 12 shows the bulk composition of the retreatphase till deposited during the glacial cycle illustrated in Figures 7 and 10 in relation to source lithologies. A series of possible source lithologies is shown, to the south of the initial and final ice divide (1 to 19) and to the north of the divide $(-1$ to -12$)$. Because of the shift of the divide to the south and then back to the north during the glacial cycle (Fig. 10), debris is carried across the divide to the north but not to the south. For the first $300 \mathrm{~km}$ to the south of the final divide, debris is only carried for a small distance beyond its source. Thereafter, an increasing proportion of the till is far-travelled, so that at the furthermost extent of the glacier to the south almost $50 \%$ of the till constituents have travelled more than $200 \mathrm{~km}$.
The increase of the mean transport distance shown in Figure 12 beyond $300-400 \mathrm{~km}$ reflects the high values of ice velocity and erosion rate in the outer zone during the ice sheet's greatest expansion. The presence of lithologies 1,2 and 3 beyond $400 \mathrm{~km}$, though they are absent between 250 and $400 \mathrm{~km}$, reflects their rapid transport during the growth phase of the ice sheet.

Figures 13 and 14 illustrate the dispersal from a single target in the model illustrated in Figure 7. Figure 13 shows a zone $0-250 \mathrm{~km}$ south of the final divide during the ice-sheet decay phase. Sediment time-distance trajectories, erosion rates and the outer depositional zone are mapped on to the time distance diagram. It is assumed that indicator erratic dispersal from a specific source will have taken place during the ice-sheet advance phase but that this will leave only trace quantities in the retreat-phase till. The furthest dispersal of erratics eroded during the retreat phase 


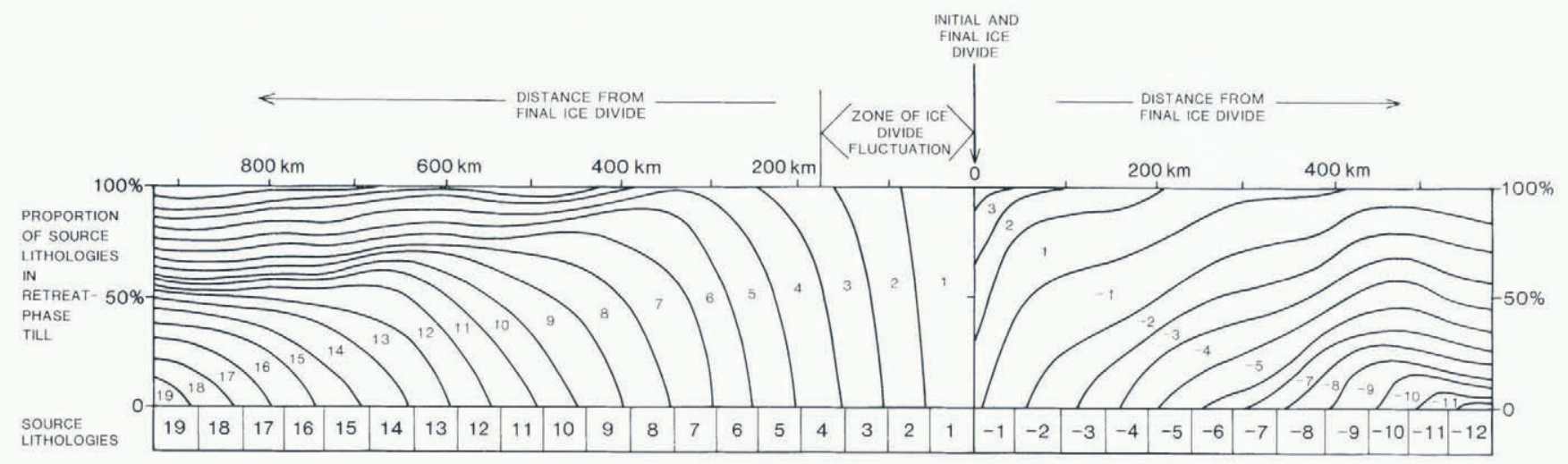

Fig. 12. The bulk lithological composition in relation to source lithology of the retreat-phase tills deposiled during the cycles shown in Figures 7 and 10. Source lithologies are shown along the boltom, 1 19 to the south of the initial final ice divide and -1 to - 12 to the north. The bulk composition of the till at any distance from the initial divide is shown in terms of the proportions derived from individual source lithologies. For instance, the lill at $400 \mathrm{~km}$ contains $45 \%$ of lithology $8,25 \%$ of lithology 7, 18\% of lithology 6, elc. Material is transported to the north across the final divide position because of the divide excursion to the south during the glacial maximum (Fig. 10) but it is not transported to the south across the divide. Note that the simplifications inherent in the ice-sheet model overestimate transport distances.

will be dictated by the furthest extent of the earliest retreat-phase trajectory derived from the source, determined in this case by the time at which the ice divide moved north of the source (Fig. 13). This earliest trajectory transported material about $100 \mathrm{~km}$ from the source before ice-sheet margin retreat past this point terminated transport of the debris package. If we consider a later trajectory which crosses the indicator source (e.g. Fig. 13, trajectory $\mathrm{O}$ ), it will have crossed the source when this coincided with a higher rate of erosion, and when the source was closer to the till which formed at the end of the trajectory, so that indicator erratics were not so diluted by subsequent debris added to the travelling sediment package. Thus, if the concentration of indicator erratics in the retreat-rate till is plotted (Fig. 15), it increases towards the indicator source. In the specific case modelled here, the peak concentration occurs some $10 \mathrm{~km}$ south of the source. This reflects the fact that, for this time distance dvnamic pattern, the greatest amount of indicator debris is picked up along trajectory $6-7$ (Fig. 13) and, although slightly diluted, it still exceeds the proportion picked up along later trajectories. The indicator erratic peak Fig. 15 can be moved nearer to or further from the source by adjusting the glacier dynamics and the retreat rate. The concentration inevitably falls to the right of the distal extremity of the source unless there are ice-front oscillations in this zone) as the period during which erosion occurred along any trajectory diminishes to the right of the distal extremity (Fig. 13).

The pattern shown in Figure 15 is similar to the classic pattern of indicator-debris decrease in a till down-ice from the indicator source (Shilts, 1976). The dispersal distance is, however, typically 220 times larger than is normally found in the central area of an ice sheet analogous to the zone modelled in Figure 15. This does not arise from the theory nor necessarily from the till rheologies used, but from the way in which the simplified ice-sheet model is used to exemplify the theory, by overemphasizing the bed-deformation component of ice- sheet movement. It may also be that the mass balance used to drive the ice-sheet flow is too large for an ice sheet during its final decay.

It is also possible to reconstruct the distribution of till lithologies from a given source in a vertical plane parallel to ice flow from the construction shown in Figure 14. Progressive till accumulation in the depositional zone is shown for a number of debris trajectories. Because of the continuous mixing process referred to above, the debris in transport along a given trajectory in the deposition zone has a constant composition. However, the till which accumulates at one place does so by deposition from a series of time distance trajectories. Because debris packages on different trajectories are of different composition, the till accumulating at one point progressively changes composition. The concentration of indicator erratics from the source shown in Figures 13 and 14 along a flow section of the retreat-phase till is shown in Figure 16. Concentration contours in the till dip in an upice direction, as is found in real examples (e.g. Kauranne and others, 1977).

As noted above, predicted erratic dispersal distances are a consequence of prescribed ice-sheet occupancy times, ice fluxes and till rheology, and the arbitrary decoupling, in the interests of simplicity, of the ice/till deformation system. Predicted dispersal distances produced by this approach cannot therefore yet be used to test the theory by comparison with observed dispersal distances. The predicted vertical patterns of erratic distribution in till can, however, be used to test the theory. The theory could then be used to infer aspects of past ice-sheet dynamics by determining the ice-sheet till parameters which produce a good fit to a particular dispersal train.

\section{ISOCHRONOUS SURFACES IN TILL}

In any depositional system, it is important to understand the pattern of sediment accumulation in time and space. 


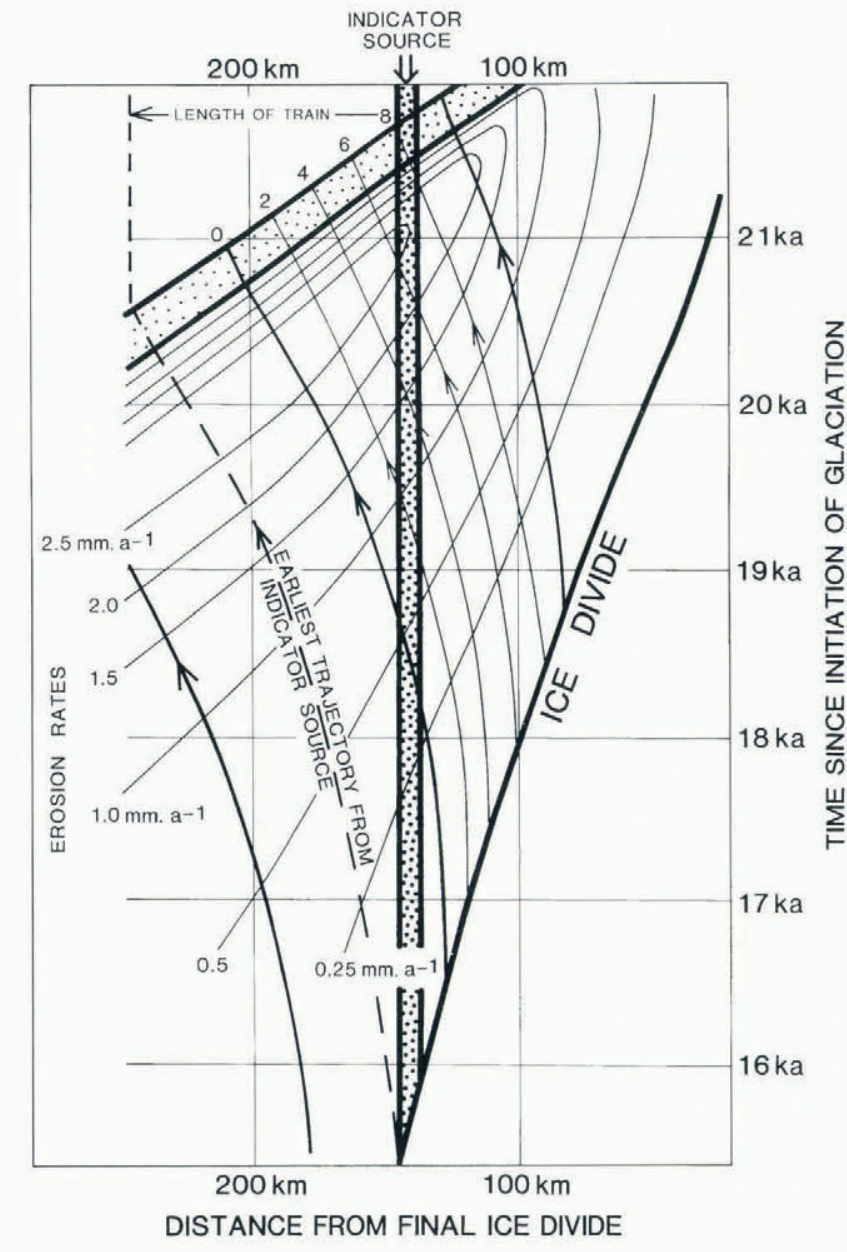

Fig. 13. Time distance properties of an ice sheel which control indicator erratic dispersal from a specific source. It shows a delail of the retreat phase of the cycle illustrated in Figures 7 and 10. Erosion rates, lime space debris transport trajectories, movement of the ice divide and the location of the depositional zone are shown. As the ice divide moves north of the indicator source site, material from it begins to be transported south. The intersection of this earliest trajectory with the retreating ice margin determines the maximum extent of dispersal from the source during the retreal phase. Sediment packages along successive trajectories which cross the source $(0-6)$ will contain increasing proportions of the indicalor lithology as the decreasing distance between the source and the location of deposition will produce less dilution of indicalor erratics in the packages, and the maximum erosion rates occur over the source when trajectories 6 and 7 cross it. This will lead to the train shown in Figures 15 and 16.

Figure 7, which shows the sequential evolution of till at a number of sites, and Figure 14, which shows accumulation of the retreat-phase till in detail, permit us to follow temporal evolution of a till by plotting isochronous surfaces within the till. In both figures, horizontal lines are time lines. Along the $21 \mathrm{ka}$ time line in Figure 14, for example, deposition was just ceasing at $205 \mathrm{~km}$ and just beginning at $180 \mathrm{~km}$, a depositional zone of $25 \mathrm{~km}$ extent. The $21 \mathrm{ka}$ isochronous surface within the till is not, however, a straight line from the top of the till at $205 \mathrm{~km}$ to its base at $180 \mathrm{~km}$. Near the up-glacier extremity of the depositional zone at $21 \mathrm{ka}$, initial desposition rates are

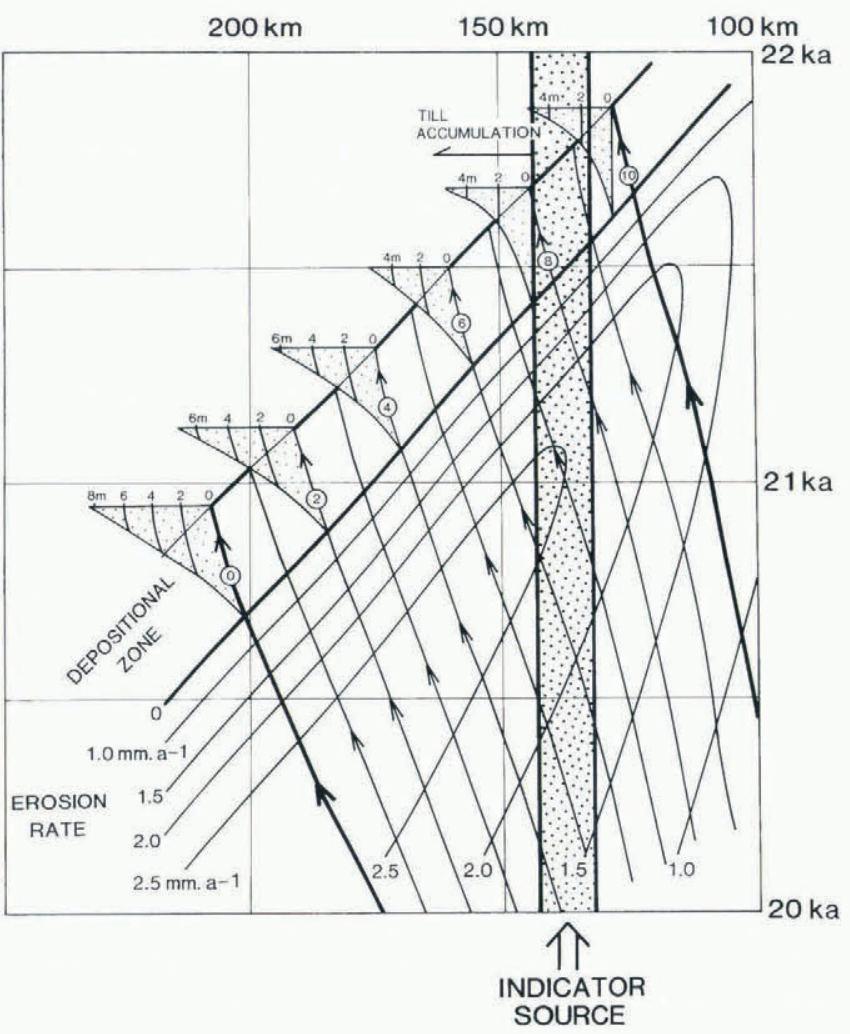

Fig. 14. Detail of Figure 13 showing the paltern of till deposition. It showes the progressive accumulation of till (cumulative thickness shown in metres) from the sediment packages travelling along lime-space trajectories 0, 2, 4 and 6 (note that horizontal lines are time lines). At $128 \mathrm{~km}$ and $144 \mathrm{~km}$, progressive accumulation of till through time at fixed locations is shown. In these two lalter cases, the till builds up in increments derived from successive lime space trajectories. As the lithological composition of succeeding sediment packages along these trajectories changes, so will the accumulating till show vertical changes in lithology. It can be seen that the base of the till accumulating at $144 \mathrm{~km}$ (the distal extremily of the indicator source) will contain a greater proportion of the indicator than higher levels, as the trajectory feeding the base has travelled for a longer period, at higher erosion rates, over the indicator source (see also Fig. 16).

slow, whilst near its down-glacier extremity, deposition rates are high (Fig. 14). Figure 16 shows the upwardly convex isochronous surfaces for till produced by the transport trajectories in Figure 14. It can also be seen from Figure 16 that isochronous surfaces cut the tilltransport trajectories, and thus that the compositional contours in the till will be steeper than isochronous surfaces, reflecting the time-transgressive advance of a compositional wave in the deforming till.

Isochronous surfaces can be complex near to the ice sheet's maximum extent, or where complex marginal fluctuations have occurred. It can be seen from Figure 7 that the advance-phase till will have isochronous surfaces along which deposition is initiated at the distal extremity of the zone of deposition (at the point where the glacier transgresses over a site) as it ceases at the proximal extremity. Thus, in contrast to the retreat-phase till, 


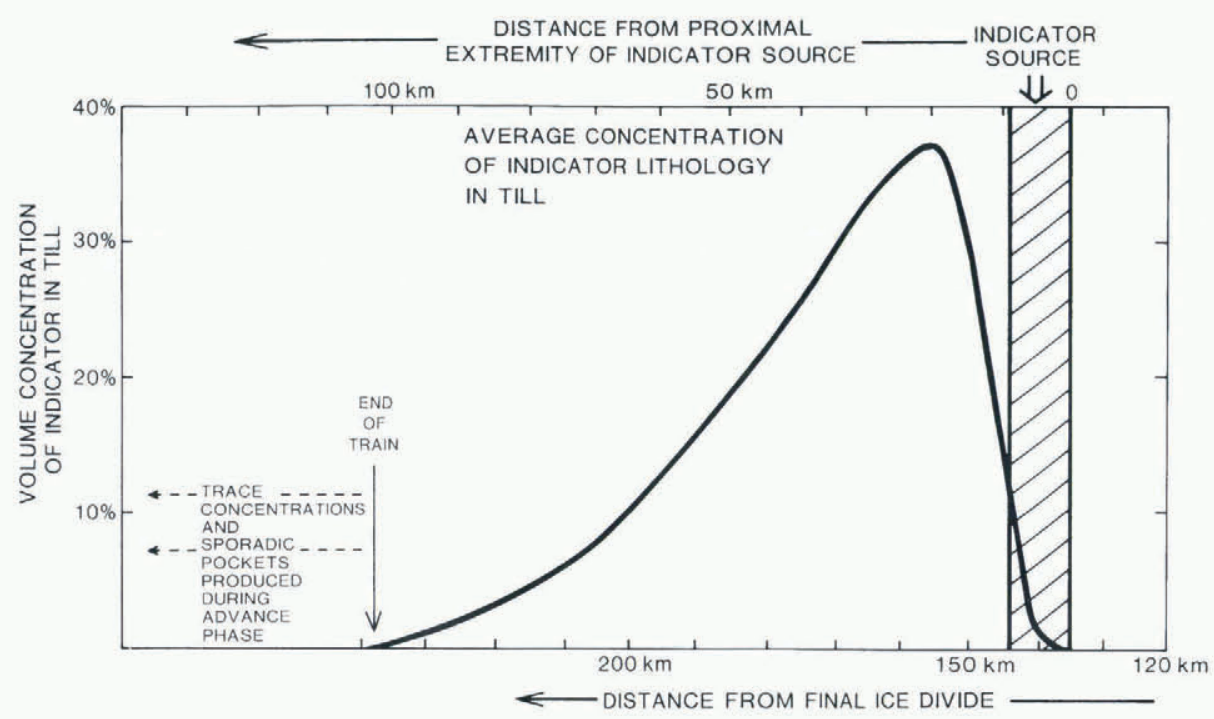

Fig. 15. Average concentration of indicator erratics in the depositional train derived from the indicator source shown in Figure 13. The earliest trajectory from the source shown in Figure 14 determines the location of the end of the train, and the peak concentration coincides with the packages deposited from trajectories 6 and 7 (Fig. 13). The length of the train and the location of the peak concentration can be changed by adjusting glacier/lill dynamics and the retreat rate.

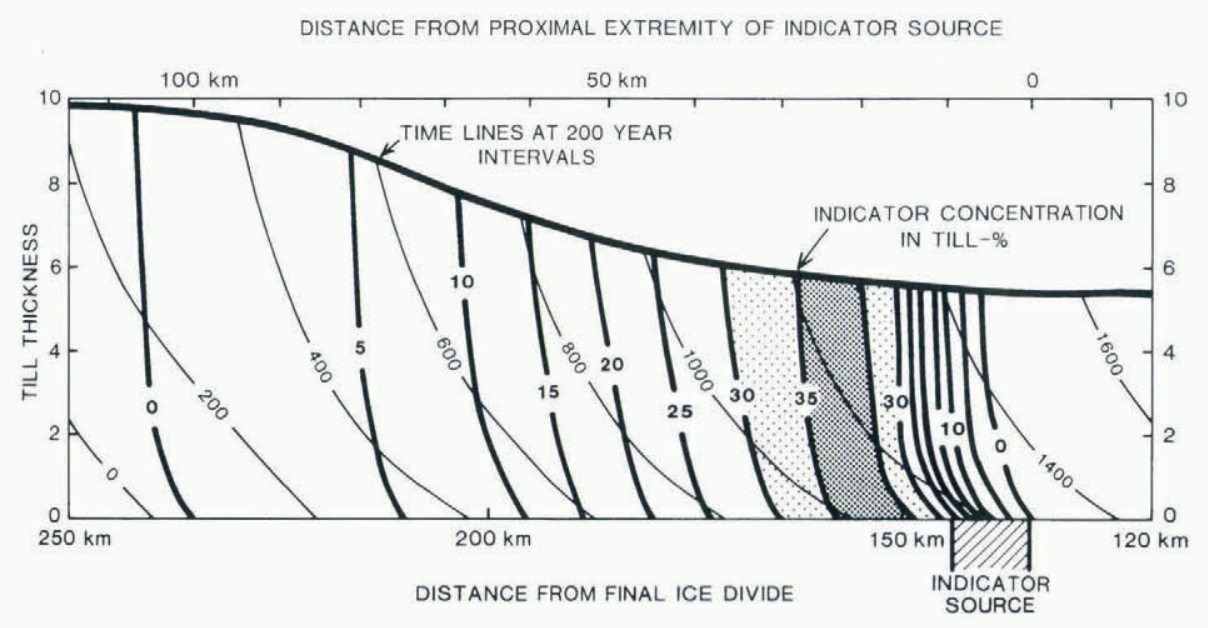

Fig. 16. Thickness, composition and isochronous surfaces in the till accumulating between $120 \mathrm{~km}$ and $250 \mathrm{~km}$ in Figure 7 . The location of the indicalor source (Figs 13 and 14) is shown and the concentration of indicalor erratics in the till. The concentrations can be derived graphically from Figure 14. Isochronous surfaces have a lower dip than the compositional anomalies. They reflect a depositional zone which is about $25 \mathrm{~km}$ in width.

isochronous surfaces will dip down-glacier from the top of the advance-phase till to its base (Fig. 17). In the terminal zone, where an advance-phase till is preserved below the retreat-phase till, though separated from it by an erosion surface, isochronous surfaces intersect the erosion surface but dip down-glacier in the advance-phase till and up-glacier in the retreat-phase till (Fig. 17). In the extreme terminal zone, where there is a gradation between advance- and retreat-phase tills, isochronous surfaces are parallel.

\section{INTRA-TILL EROSIONAL SURFACES AND BOULDER PAVEMENTS}

The theory suggests that, near to the maximum extent of a glacier advance or re-advance, we should expect a zone in which the advance-phase till has been partially eroded before further till is deposited during the retreat phase.

Erosion due to sediment deformation takes place by lowering the interface between the rapidly deforming A horizon and the stable $\mathrm{B}$ horizon (Fig. 18b). The uppermost part of the B horizon, as it fails and begins to deform, dilates, takes in further pore water and is reduced in density. The bulk density of the deforming matrix will be much smaller than that of individual clasts. In experiments at Breidamerkurjökull Boulton and Hindmarsh, 1987), matrix bulk density in a sandy till was typically between 0.6 and 0.65 of the clast density. The material was near to the liquid limit and there was therefore a tendency for clasts to sink through the matrix (Lawson, 1982), a tendency counteracted by the mixing induced by frequent folding events as a consequence of the irregularity of the $\mathrm{A} / \mathrm{B}$ interface. 


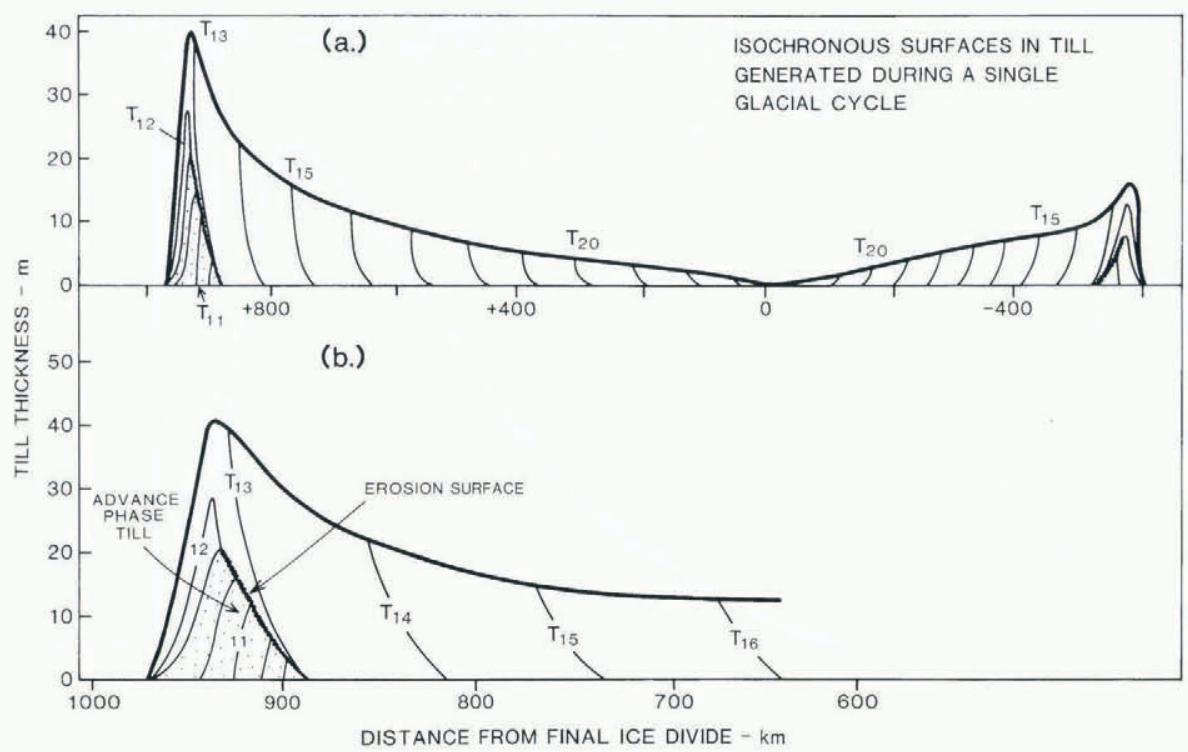

Fig. 17. Isochronous surfaces in the till generated as a result of the glacial cycle shown in Figure 7. (b) is an enlarged version of the lefithand side of $(a)$. The time lines $\left(T_{10} T_{23}\right)$ are in thousands of years after initiation of the glacial cycle. Note that the dip is down-ice in the advance-phase till and up-ice in the retreat phase.

(a.) ADVANCE PHASE DEPOSITION (b.) EROSIVE PHASE (c.) RETREAT PHASE DEPOSITION
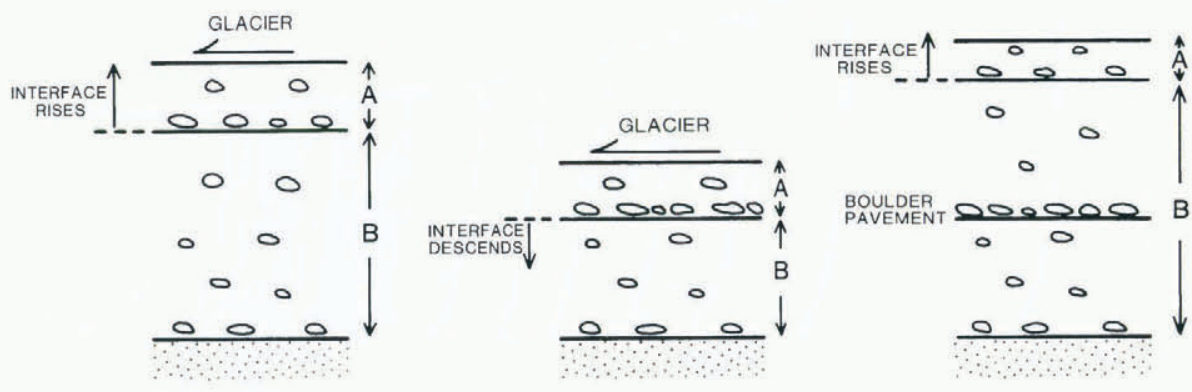

Fig. 18. Formation of a boulder pavement in till. (a) Boulder distribution during deposition. Till deposition occurs due to the rise of the interface between the $A$ and $B$ horizons. There is no lendency for boulder concentration at any specific horizon, as all levels in the till have once been at the $A / B$ interface and any one is as likely to have a boulder concentration as any other. (b) Boulder concentration at the descending $A / B$ interface during erosion. As the $A / B$ interface descends around a boulder, the lift force in the relatively low-density deforming horizon may not be enough to move the boulder above the $A / B$ plane. Consequently, boulders will tend to be concentrated at the interface as it descends. (c) As a phase of deposition succeeds the erosion phase, the A/B interface again begins to rise and a boulder pavement is left marooned in the till, marking the lowest level to which the A/B plane descended during erosion. As in (a), there is no tendency for boulder pavements to develop during deposition.

During deposition of till (Fig. 18a), there is no tendency for boulder concentrations to develop at any specific horizon, as all horizons have, at some time, coincided with the rising A/B plane. During subsequent erosion due to descent of the $A / B$ interface, whereas we would expect dilatant matrix to move readily into the deforming mass and to be involved in the mixing process of folding, the dense clasts, on being exposed above the descending $\mathrm{A} / \mathrm{B}$ interface, would resist being drawn into the flow. They would tend to remain immediately above the descending $\mathrm{A}$ $\mathrm{B}$ interface, thus concentrating larger clasts from the mobilized till at the A/B interface (Fig. 18b).

It is only where part of the advance-phase till has survived subsequent erosion, such as at about $900 \mathrm{~km}$ in Figure $7 \mathrm{~b}$, that a boulder pavement develops (Dreimanis, 1976). It will be left at the lowest point to which the $A / B$ plane descends. Subsequent deposition during the retreat phase will preserve this erosional interface and its boulder concentration (Fig. 18c).

It is therefore suggested that the intra-till erosional surfaces, such as those shown in Figures 7 and 17, will tend to be marked by boulder pavements. Whether or not this occurs will depend on the matrix/clast density contrast during deformation and the "lift" forces developed during folding episodes.

It has been suggested by Boulton and Hindmarsh 
(1987; see fig. 8-iv) and Boulton and Dobbie (1993) that under certain conditions the $\mathrm{A} / \mathrm{B}$ interface will be a sliding interface rather than merely a narrow zone of very high shear strain. No matter which of these it is, but particularly in the former case, we might expect some erosion of the top surface of a boulder pavement to be produced by movement of a till slurry over them. If the boulders of the pavement are stable, which they will tend to be if they penetrate beneath the $\mathrm{A} / \mathrm{B}$ interface, they may acquire a systematic pattern of striation reflecting the direction of till deformation over them. This has been observed from time to time on boulder pavements (Elson. 1957). If boulder pavements are a product of inter-till erosion, lithological contrasts will tend to occur between overlying and underlying tills.

Clark (1991) has suggested that boulder pavements will simply form at the base of a deforming horizon because of sinking through the matrix. I suggest, however, that this will only occur where erosion, which is the source of deformation till, occurs.

\section{CONGLUSIONS}

(1) A theory of erosion, transport and deposition is developed for an ice sheet where the dominant mode of transport is by subglacial sediment deformation. The flux of glacially transported sediment is related to the ice flux. It tends to increase distally in the accumulation area and decrease distally in the ablation area. As a consequence, the inner zone of an ice sheet is predominantly one of erosion and the outer zone one of deposition.

2) Modelling a simple cycle of growth and decay of an ice sheet with a fixed ice divide shows a resultant pattern of a divide zone with little erosion and thin till, an intermediate zone of increasing erosion depth and till thickness and an outer zone of little or zero erosion and large till thicknesses. In the inner and intermediate zone, the resultant till is deposited during the decay phase. In the outer zone, till from the advance phase survives beneath the decay-phase till. There are gradational contacts between the two in the outermost zone, whilst a little further from the outer limit, an erosion zone, which may be marked by a boulder pavement, intervenes between them.

(3) If ice divides shift during the glacial cycle, earlier tills can be preserved beneath the relatively inactive divide zone. Earlier tills can also be preserved in areas which lay beneath inter-ice-stream ridges, where low ice-flux rates are expected.

(4) The theory permits the pattern of glacial dispersal of debris to be computed through a glacial cycle. In general, it predicts that the mean derivation distance of till lithologies will tend to increase upwards in any one sequence; that the derivation distance will increase distally; and that sharp contrasts in till lithology will occur across erosional interfaces.

(5) The depth and pattern of erosion, the thickness, composition and distribution of tills, the strength of lineations and the dispersal of erratics during glacial cycles all depend on both large-scale, climatically determined ice-sheet dynamic properties, and smallscale attributes of the ice-sheet bed. In climatically maritime areas of large vertical mass-balance gradients, the resultant energetic ice sheets will produce more erosion, thicker tills and stronger lineation than in a continental area of smaller mass-balance gradient.

6) Extensive subglacial aquifers will tend to drain the glacier bed and inhibit the deformation process, thereby reducing rates of erosion and deposition.

(7) Fine-grained sediments on the glacier bed will tend to be eroded and transported more readily than coarsegrained sediments and thus contribute preferentially to the resultant till. This process is a principal determinant of till lithology and explains why tills will tend to be enriched in the finer-grained sediments available in the area over which the glacier has expanded.

8) Large-scale reconstructions of till-thickness distribution and drift lineation produced during former glacial periods, and large-scale patterns of erratic distribution in tills can be used to reconstruct glacier dynamic history.

\section{ACKNOWLEDGEMENTS}

Thanks are due to N. Hulton, P. Caban, R. Hindmarsh, N. Dalgleish, M. Punkari, K. Boulton and S. Zatsepin for valuable discussions during the preparation of this paper. Much of the work was funded by grants from the U.K. Natural Environment Research Council.

\section{REFERENCES}

Alley, R. B. 1992. How can low-pressure channels and deforming tills coexist subglacially? J. Glaciol., 38 128 , 200207.

Alley, R. B., D. D. Blankenship, C. R. Bentley and S. T. Roones, 1987. Till beneath Ice Stream B. 3. Till deformation: evidence and implications. J. Geophys. Res., 92 B9 89218929.

Alley, R. B.. D. D. Blankenship, S. T. Rooney and C. R. Bentles. 1989 Sedimentation beneath ice shelves the view from Ice Stream B. Mar. Geol., $852 / 4,101120$.

Andrews, J. T., P. Clark and J. A. Stravers. 1985. The patterns of glacial erosion across the eastern Canadian Aretic. In Andrews. J. T.. ed. Quaternary environments; castern Canadian Arctic. Baffin Bay and western Greenland. Boston, MA, etc.. Allen and Unwin, 6992.

Boulton, G.S. 1974. Processes and patterns of glacial crosion. In Coates. D. R., ed. Glacial geomorpholog). Binghampton, State University of New York, $41-87$.

Boulton, G. S. 1979. Processes of glacier erosion on dillerent substrata. J. Glaciol., 2389 , 15 38.

Boulton, G.S. 1987. A theory of drumlin formation by subglacial sediment deformation. In Menzies. J. and J. Rose. eds. Drumlin Simposium. Rotterdam. A. A. Balkema Publishers, 2580.

Boulton. G.S. 1990. Sedimentary and sea level changes during glacial cycles and their control on glacimarine facies architecture. In Dowdeswell. J. A. and J. D. Scourse. eds. Glacimarine emionments: processes and sediments. London, The Geological Society. 1552. Special Publication 53.

Boulton, G.S. and C.D. C.lark. 1990. A highly mobile Laturentide ice sheet revealed by satellite images of glacial lincations. lature. 3466287 , 813817.

Bouton, G.S. and K.E. Dobbie. 1993. Consolidation of sediments b) glaciers: relations between sediment geotechnics, soft-bed glacier dynamics and subglacial ground-water flow. F. Cilaciol.. 39 131, 26 14. 
Boulton, G.S. and R. C. A. Hindmarsh. 1987. Sediment deformation beneath glaciers: rheology and geological consequences. J. Geophys. Res., 92 B9), 90599082.

Boulton, G. S. and A. S. Jones. 1979. Stability of temperate ice caps and ice sheets resting on beds of deformable sediment. F. Glaciol., 2490 , $29-43$.

Boulton, G.S. and A. Payne. 1992. Simulation of the European ice sheet through the last glacial ocle and prediction of future glaciation. Stockholm, etc., Svensk Kärnbräslehantering AB. SKB Technical Report 9314.)

Boulton, G. S.. T. Slot, K. Blessing, P. Glasbergen and K. van Gijssel. 1993. Deep circulation of groundwater in overpressured subglacial aquifers and its geological consequences. Quat. Sci. Rev. 12, $739-745$.

Clark, P. U. 1991. Striated clast pavements: products of deforming subglacial sediment? Geology, $195,530-533$.

Clark, P. U. and J.S. Walder. 1994. Subglacial drainage, eskers, and deforming beds beneath the Laurentide and Eurasian ice sheets. Geol. Soc.

Clarke, G.K.C. 1987. Subglacial till: a physical framework for its properties and processes. J. Geophys. Res., 92 B9), 9023-9036.

Dobbie, K.E. 1992. Till geotechnics and ice sheet dynamies. Ph.D. thesis, University of Edinburgh.

Dreimanis, A. 1976. Tills: their origin and properties. In Legget, R. F., ed. Glacial till: an inter-disciplinary study. Ottawa, Royal Society of Canada, 11-49. Special Publication 12.

Ehlers. J.. P. L. Gibbard and J. Rose. eds. 1991. Quaternary deposits in Great Britain and Ireland. Rotterdam, A. A. Balkema.

Elson, J. A. 1957. Striated boulder pavements of southern Manitoba, Canada. Geol. Soc. Am. Bull., 68, 1722.

Engelhardt, H., N. Humphrey, B. Kamb and M. Fahnestock. 1990. Physical conditions at the base of a fast moving Antarctic ice stream. Science, 248 4951), $57-59$.

Eyles, N. 1983. Glacial geology: an introduction for engineers and earth scientisls. London, Pergamon Press.

Fountain, A. G. 1994. Borehole water-level variations and implications for the subglacial hydraulics of South Cascade Glacier, Washington State, U.S.A. J. Glaciol., 40 135), 293304.

Fowler, A. and J. Walder. 1993. Creep closure of channels in deforming subglacial till. Proc. R. Soc. London. Ser. A, 441 (1911), 17-31.

Goldthwait, R. P. 1960. Study of ice cliff in Nunatarssuaq, Greenland. SIPRE Tech. Rep. 39.

Hindmarsh, R. C.A., G.S. Boulton and K. Hutter. 1989. Modes of operation of thermo-mechanically coupled ice sheets. Ann. Glaciol., 12. 5769 .

Hughes, T. 1977. West Antarctic ice streams. Rev. Geophys. Space Phys., 15 ( ) , 1- 46.

Jellinek, H. H. G. 1959. Adhesive properties of ice. 7. Colloid Sci.. 14 3), 268280.

Kamb, W. B. 1991. Rheological nonlinearity and flow instability in the deforming-bed mechanism of ice-stream motion. \%. Geophys. Res., $96 \mathrm{~B} 10,16,585-16,595$.

Kauranne, K.. R. Salminen and M. Ayräs. 1977. Problems of geochemical contrast in Finnish soils. In Prospecting in areas of glaciated terrain 1977. Otaniemi. Finland. London, Institution of Mining and Metallurgy, 3444.

Kleman. J. 1990. On the use of glacial striae for reconstruction of paaleoice sheet flow patterns - with application to the Scandinavian ice sheet. Geogr. Ann., 72A 3 4), 217-236.

Lagerbäck, R. 1988. The Veiki moraines in northern Sweden widespread evidence of an early Weichselian deglaciation. Boreas, 17, $469-486$.

Lawson, D. E. 1982. Mobilization, movement and deposition of active subaerial sediment flows, Matanuska Glacier, Alaska. J. Geol., 90 3), 279-300.

Mackay, J. R. 1959. Glacier ice-thrust features of the Yukon coast. Geogr. Bull., 13, $5-21$.

Morland, L. W. 1984. Thermo-mechanical balances of ice sheet flow. J Geophys. Astrophys, Fluid Dyn., 29, $237-266$.

Nye, J. F. 1959. The motion of ice sheets and glaciers. f. Glaciol., 3 26). 493507.

Nye, J. F. 1973. Water at the bed of a glacier. International Association of Scientific Hydrology Publication 95 Symposium at Cambridge 1969 Hydrology of Glaciers), 189-194.

Perrin, R.M.S., J. Rose and H. Davies. 1979. The distribution. variation and origin of pre-Devensian tills in eastern England. Philos. Trans, R. Soc. London, Ser. B, 287, $537-570$.

Punkari, M. 1980. The ice lobes of the Scandinavian ice sheet during the deglaciation in Finland. Boreas, 9 4), 307310.

Rappol, M., S. Haldorsen, P. Jorgensen, J.J. .. van der Meer and H. M. P. Stoltenberg. 1989. Composition and origin of petrographically stratified thick till in the northern Netherlands and a Saalian glaciation model for the North Sea basin. Meded. Werkgr. Tert. Kwart. Geol., 26, $31-64$.

Rose, J. and J. M. Letzer. 1977. Superimposed drumlins. F. Glaciol., $1880), 471-480$.

Röthlisberger, H. 1972. Water pressure in intra- and subglacial channels. 7. Glaciol., 1162 ), $177-203$.

Shilts, W. W. 1976. Glacial till and mineral exploration. In Legget, R. F., ed. Glacial till: an inter-disciplinary study. Ottawa, Royal Society of Canada, 205 224. Special Publication 12.

Sugden, D. E. 1977. Reconstruction of the morphology, dynamics and thermal characteristics of the Laurentide Ice Sheet at its maximum. Arcl. Alp. Res., 9 1), 2147.

Weertman, J. 1972. General theory of water flow at the base of a glacier or ice sheet. Rer. Geophys. Space Plys., 10 1), 287-333.

White, W. A. 1972. Deep erosion by continental ice sheeets. Geol. Soc. Am. Bull., 83 4), 1037-1056. 